\title{
Complex characterization of oat (Avena sativa L.) lines obtained by wide crossing with maize (Zea mays L.)
}

Edyta Skrzypek ${ }^{\text {Corresp., }}{ }^{1}$ ， Tomasz Warzecha ${ }^{2}$, Angelika Noga ${ }^{1}$, Marzena Warchoł ${ }^{1}$, Ilona Czyczyło-Mysza ${ }^{1}$, Kinga Dziurka $^{1}$, Izabela Marcińska ${ }^{1}$, Kamila Kapłoniak ${ }^{1}$, Agnieszka Sutkowska ${ }^{2}$, Zygmunt Nita ${ }^{3}$, Krystyna

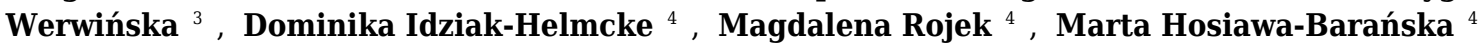

1 Department of Biotechnology, Polish Academy of Sciences The Franciszek Górski Institute of Plant Physiology, Kraków, Poland

2 Department of Plant Breeding and Seed Science, University of Agriculture, Kraków, Polska

3 Plant Breeding Strzelce Ltd., PBAI Group, Strzelce, Polska

4 Department of Plant Anatomy and Cytology, University of Silesia in Katowice, Katowice, Polska

Corresponding Author: Edyta Skrzypek

Email address: e.skrzypek@ifr-pan.edu.pl

Background: The oat $\times$ maize addition (OMA) lines are used for mapping of the maize genome, the studies of centromere-specific histone (CENH3), gene expression, meiotic chromosome behavior and also for introducing maize C4 photosynthetic system to oat. The aim of our study was the identification and molecular-cytogenetic characterization of oat $x$ maize hybrids. Methods: Oat DH lines and oat $\times$ maize hybrids were obtained using the wide crossing of Avena sativa L. with Zea mays L. The plants identified as having a Grande-1 retrotransposon fragment, which produced seeds, were used for genomic in situ hybridization (GISH). Results: A total of 138 oat lines obtained by crossing of 2314 oat plants from 80 genotypes with maize $\mathrm{cv}$. Waza were tested for the presence of maize chromosomes. The presence of maize chromatin was indicated in 66 lines by amplification of the PCR product (500 bp) generated using primers specific for the maize retrotransposon Grande-1. Genomic in situ hybridization (GISH) detected whole maize chromosomes in 8 lines (40\%). All of the analyzed plants possessed full complement of oat chromosomes. The number of maize chromosomes differed between the OMA lines. Four OMA lines possessed 2 maize chromosomes similar in size, three OMA - one maize chromosome, and one OMA - four maize chromosomes. In most of the lines, the detected chromosomes were labeled uniformly. The presence of six 45S rDNA loci was detected in oat chromosomes, but none of the added maize chromosomes in any of the lines carried $45 S$ rDNA locus. Twenty of the analyzed lines did not possess whole maize chromosomes, but the introgression of maize chromatin in the oat chromosomes. Five of 66 hybrids were shorter in height, grassy type without panicles. Twenty-seven OMA lines were fertile and produced seeds ranging in number from 1 - 102 (in total 613). Sixty-three fertile DH lines, out of 72 which did not have an addition of maize chromosomes or chromatin, produced 
seeds in the range of 1 - 343 (in total 3758). Obtained DH and OMA lines were fertile and produced seeds. Discussion: In wide hybridization of oat with maize, the complete or incomplete chromosomes elimination of maize occur. Hybrids of oat and maize had a complete set of oat chromosomes without maize chromosomes, and a complete set of oat chromosomes with one to four retained maize chromosomes. 
1 Complex characterization of oat (Avena sativa L.) lines obtained by wide crossing with maize

2 (Zea mays L.)

3

4 Edyta Skrzypek ${ }^{1}$, Tomasz Warzecha ${ }^{2}$, Angelika Noga ${ }^{1}$, Marzena Warchoł ${ }^{1}$, Ilona Czyczyło5 Mysza $^{1}$, Kinga Dziurka ${ }^{1}$, Izabela Marcińska1, Kamila Kapłoniak ${ }^{1}$, Agnieszka Sutkowska ${ }^{2}$, 6 Zygmunt $\mathrm{Nita}^{3}$, Krystyna Werwińska ${ }^{3}$, Dominika Idziak-Helmcke ${ }^{4}$, Magdalena Rojek ${ }^{4}$, Marta 7 Hosiawa-Barańska ${ }^{4}$

8

$9{ }^{1}$ Polish Academy of Sciences, The Franciszek Górski Institute of Plant Physiology, Department of Biotechnology, Niezapominajek 21, 30-239 Kraków, Poland

11 Corresponding author e-mail: e.skrzypek@ifr-pan.edu.pl

12

${ }^{2}$ University of Agriculture, Department of Plant Breeding and Seed Science, Łobzowska 24, 31140 Kraków, Poland

${ }^{3}$ Plant Breeding Strzelce Ltd., PBAI Group, Główna 20, 99-307 Strzelce, Poland

${ }^{4}$ University of Silesia in Katowice, Department of Plant Anatomy and Cytology, Jagiellońska 28, 40-032 Katowice, Poland

\section{Abstract}

The oat $\times$ maize addition (OMA) lines are used for mapping of the maize genome, the studies of centromere-specific histone $(\mathrm{CENH} 3)$, gene expression, meiotic chromosome behavior and also for introducing maize $\mathrm{C} 4$ photosynthetic system to oat. The aim of our study was the identification and molecular-cytogenetic characterization of oat $\times$ maize hybrids. A total of 138 oat lines obtained by crossing of 2314 oat plants from 80 genotypes with maize cv. Waza were tested for the presence of maize chromosomes. The presence of maize chromatin was indicated in 66 lines by amplification of the PCR product $(500 \mathrm{bp}$ ) generated using primers specific for the maize retrotransposon Grande-1. Genomic in situ hybridization (GISH) detected whole maize chromosomes in 14 lines (70\%). All of the analyzed plants possessed full complement of oat 
32 chromosomes. The number of maize chromosomes differed between the OMA lines. Twelve OMA

33 lines possessed 2 maize chromosomes similar in size, one OMA - one maize chromosome, and one OMA - four maize chromosomes. In most of the lines, the detected chromosomes were labeled uniformly. The presence of six 45S rDNA loci was detected in oat chromosomes, but none of the added maize chromosomes in any of the lines carried 45S rDNA locus. Four of the analyzed lines did not possess whole maize chromosomes, but the introgression of maize chromatin in the oat chromosomes. Five of 66 hybrids were shorter in height, grassy type without panicles. Twentyseven OMA lines were fertile and produced seeds ranging in number from 1-102 (in total 613). Sixty-three fertile DH lines, out of 72 which did not have an addition of maize chromosomes or chromatin, produced seeds in the range of $1-343$ (in total 3758). All DH and OMA lines were fertile and produced seeds.

\section{Introduction}

The fusion of genomes from various genetic backgrounds through wide hybridization is essential for plant breeders seeking new crop cultivars, especially in the context of climate changes. On the other hand, unlikely hybrids with genomes from both the parental species are not always obtained. Uniparental chromosome elimination, the removal of the one parent chromosomes from the wide hybrids, might be a benefit to the breeders for fast genetic improvement of the crop cultivars (Chaudhary et al. 2014).

In crosses between Panicoideae and Pooideae, in hybrids e.g. wheat $\times$ sorghum, wheat $\times$ pearl millet, wheat $\times$ maize, oat $\times$ maize or oat $\times$ pearl millet, either Panicoideae chromosomes are eliminated shortly after fertilization at the beginning of embryogenesis, or incomplete chromosomes elimination occurred (Laurie and Bennett 1986, 1988; Laurie 1989; Rines and Dahleen 1990). In the case of maize crosses, the elimination of maize chromosomes was due to their limited mobility for the duration of mitotic metaphase and anaphase as a result of the failure of spindle fiber attachment to the centromeres (Laurie and Bennett 1989).

Chromosome elimination of the alien genome after fertilization of the different species can take place in various distant hybrids (Dunwell 2010). Interspecific hybridization was the first observed in the genus Hordeum, during crossing cultivated barley (Hordeum vulgare L.) as the female with wild species Hordeum bulbosum L. (Kasha and Kao, 1970). In an early stage of development of a hybrid embryo, chromosomes of the female are eliminated and developed 
63 haploid embryos contain only chromosomes of cultivated barley (Liu et al. 2014). Chromosome 64 elimination has been described in crosses of Triticum aestivum and Triticeae species (H. vulgare and H. bulbosum) as well as more distantly related species (Zea mays, Pennisetum glaucum, Sorghum bicolor, Coix lacryma-jobi, Imperata cylindrica) (Barclay 1975; Laurie and Bennett 1986, 1988; Laurie 1989; Inagaki and Mujeeb-Kazi 1995; Mochida and Tsujimoto 2001; Gernand et al. 2005; Komeda et al. 2007; Chaudhary et al. 2013).

A new situation was observed in the crosses between oat (Avena sativa L.) and maize (Zea mays L.) where oat $\times$ maize hybrid embryos developed into euhaploid plants with the whole oat chromosomes without maize chromosomes and into aneuhaploid plants with the complete set of oat chromosome and added a different numbers of maize chromosomes (Kynast et al. 2012). In the aneuhaploid plants numerous maize chromosomes were not removed during embryogenesis, and the preserved maize chromosomes ultimately were stable and act as oat chromosomes in mitosis. The consequence of it was obtaining oat $\times$ maize addition (OMA) lines.

The first sweet maize line used to obtain OMA was the Seneca 60. In oat was identified a fragment of Seneca 60 chromosome 3 containing a neocentromere (Topp et al. 2009). Over the past few years, fertile disomic OMA of diverse oat cultivars have been reported, in which Zea mays was the recipient of chromosomes 1-7 and 9, the short arm of 10, as well as a monosomic OMA with chromosome 8 (Rines et al. 2009). Amongst maize crosses with other cereals, only oat $\times$ maize hybrids formed embryos which are able to germinate and grow into partially fertile plants. In these OMA lines the partial fertility is a result of meiotic restitution, which improved the production of unreduced gametes. The observation of haploid oat microsporocytes (with or without maize chromosomes) displayed that in microsporogenesis karyokinesis is irregular, mainly in meiosis (Kynast et al. 2012).

Ishii et al. (2013) reported that in crosses of oat $\times$ pearl millet (Pennisetum glaucum L.), chromosome and marker analyses showed that the seedlings were hybrids that had all oat and some pearl millet chromosomes. Twenty one embryos in this study germinated and showed only shoot growth which turned to the scutellum and finally died under light regime.

The OMA lines are irreplaceable and valuable genetic materials, where the heterologous organism is required to investigate the role and structure of single maize chromosome, to ascribe and localize molecular markers and genes on maize chromosomes, or to study the dynamic of chromosome pairing. Dissecting the maize chromosomes by OMA lines can deliver plants with 
94 95 96

maize subchromosomal fragments. As OMA lines, subchromosomal materials are used in a series of genomics and chromosome studies (Kynast and Riera-Lizarazu 2011).

The OMA lines were used in the cytogenetic mapping system for maize genome (RieraLizarazu et al. 1996; Maquieira 1997; Kynast et al. 2001, 2002; Okagaki et al. 2001; Koumbaris and Bass 2003), gene expression (Jin et al. 2004), meiotic chromosome arrangements (Bass et al. 2000), investigation of conservation of gene expression of prolamin storage protein (Garcia et al. 2015) as well as investigation of genes transcriptional regulation in new genomic environments (Dong et al. 2018). It was shown that the majority of maize genes displayed maize-specific transcription in the oat genomic environment. Oat $\times$ maize hybrids were also used for identification (Topp et al. 2009) and analyzing the size and location of maize chromosomes centromeres transferred into oat by immunoprecipitation for the histone CENH3 (Wang et al. 2014). The mutation of CENH3 offers promising opportunities for application in a wide range of crop species for haploid production (Ravi and Chan 2010; Ishii et al. 2015; Karimi-Ashtiyani et al. 2015; Maheshwari et al. 2015; Britt and Kuppu 2016; Kelliher et al. 2016). A single-point amino acid exchange in the centromere-targeting domain of CENH3 leads to reduced centromere loading of CENH3 in barley, sugar beet, and Arabidopsis thaliana. Haploids were obtained when cenh3-null mutants were crossed with desired plants. The OMA lines were also used in the examination for expression of the $\mathrm{C}_{4}$ photosynthetic system (Kynast et al. 2001; Kowles et al. 2008; Dong et al. 2018).

The aim of the study was the identification and molecular-cytogenetic characterization of oat $\times$ maize hybrids. The paper also presents vigor of DH and OMA lines and their effectiveness in seeds production.

\section{Material and Methods}

Oat wide crossing with maize

The experiments were done on 80 oat genotypes (listed in Table 1) obtained from Plant Breeding Strzelce Ltd., PBAI Group, Strzelce, Łódź Voivodeship, Poland. Oat plants and maize cultivar Waza were sown and cultivated according to Noga et al. (2016). Oat haploid plants were obtained using the wide crossing method by pollination with maize cv. Waza, as described by Marcińska et al. (2013). Three weeks after floret pollination, enlarged ovaries were sterilized in $70 \%(v / v)$ ethanol $(1 \mathrm{~min})$, in a $2.5 \%(w / v)$ calcium hypochlorite $(8 \mathrm{~min})$, and washed three times with sterile 
125 water. Then, haploid embryos were isolated from caryopses and transferred to the 190-2 medium

126 (Zhuang and $\mathrm{Xu}, 1983)$ with 9\% (w/v) maltose, $0.6 \%(w / v)$ agar, $0.5 \mathrm{mg} \mathrm{L}^{-1}$ kinetin (KIN) and 0.5

$127 \mathrm{mg} \mathrm{L}^{-1} \alpha$-naphthaleneacetic acid (NAA) and $\mathrm{pH}$ 6.0. Haploid embryos were germinated in an in

128 vitro chamber with a $16 \mathrm{~h}$ photoperiod, light intensity of $100 \mu \mathrm{mol} \mathrm{m} \mathrm{s}^{-1}$ and temperature $21^{\circ} \mathrm{C}$.

129 The germination capacity of haploid embryos was evaluated under a stereomicroscope (SMZ 1500,

130 Nikon, Tokyo, Japan) and photographs were taken using a digital CCD camera (DS-Ri1, Nikon,

131 Tokyo, Japan).

132 The plants developed from haploid embryos were transferred to MS medium (Murashige 133 and Skoog, 1962) with $0.6 \%(w / v)$ agar. Then, the well rooted plants were acclimated to natural 134 conditions by transferring them subsequently to wet perlite and soil. For chromosome doubling, 135 the roots of haploid plants were treated by colchicine solution and the ploidy level of the plants 136 was evaluated using a MACSQuant flow cytometer (MACSQuant, Miltenyi Biotec GmbH, 137 Bergisch Gladbach, Germany) as described by Noga et al. (2016).

Next, the plants were tested for the presence of the maize retrotransposon Grande-1 to 139 indicate maize chromatin in oat. Oat cv. Stoper and maize cv. Waza were used as a negative and positive control of the presence of the maize retrotransposon Grande-1. Leaves of studied lines, oat cv. Stoper, and maize cv. Waza (about $200 \mathrm{mg}$ ) were lyophilized in high vacuum at $40 \mu \mathrm{bar}$, coil temperature $-52^{\circ} \mathrm{C}$ (lyophiliser FreeZone 6L, Labconco, USA). Then, the tissue was homogenized using ball mill (MM400, Retsch, Germany) for $5 \mathrm{~min}$ at frequency $25 \mathrm{~Hz}$.

DNA extraction and PCR analyses

DNA was extracted from $20 \mathrm{mg}$ of lyophilized leaves, using the Genomic Mini AX Plant kit (A\&A Biotechnology) according to the producer recommendations. After precipitation, the DNA pellet was washed twice in $70 \%(\mathrm{v} / \mathrm{v})$ ethanol and dried in a concentrator (Concentrator Plus, Eppendorf, Germany) for $10 \mathrm{~min}$. under $20 \mathrm{hPa}$. The precipitate was suspended in sterile distilled water. DNA concentration was measured at $260 \mathrm{~nm}$ with a spectrophotometer NanoDrop 2000c (Thermo Scientific, USA).

153 TGG TTC ATG CCG ATT GCA CG-3' ) primers (GenBank Accession No. X97604; Ananiev et 154 al., 1998) were used for the PCR reaction, which in successive cycles enabled the amplification of 
155 the $500 \mathrm{bp}$ retrotransposon region of Grande-1 and detection of the presence of maize chromatin

156 in oat plants. For the PCR, the thermostable Taq polymerase (Fermentas, USA) was used.

157 After DNA isolation and dilution $(50 \mu \mathrm{g} / \mu \mathrm{l}$ DNA $), 5 \mu \mathrm{l}$ of DNA was taken and introduced

158 into reaction mixture using $0.5 \mu \mathrm{l}$ of each two primers. The reaction mixture was placed in a

159 thermocycler (2720 Thermal Cycler, Applied Biosystems, USA) and used the following thermal

160 program: 1 . Initial denaturation $-94{ }^{\circ} \mathrm{C}, 5$ min.; 2. Cyclic denaturation: $94{ }^{\circ} \mathrm{C}-30 \mathrm{~s} ; 3$. Starter

161 connection $-58{ }^{\circ} \mathrm{C}, 30 \mathrm{~s} ; 4$. Polymerization $-72{ }^{\circ} \mathrm{C}-30 \mathrm{~s}$; 5 . Final Polymerization $-72{ }^{\circ} \mathrm{C}, 5 \mathrm{~min}$.

162 Stages 2-4 were repeated cyclically 25 times. In the last stage the samples were cooled to $4{ }^{\circ} \mathrm{C}$

163 until removed from the amplification apparatus (Ananiev et al. 1998).

164 The obtained products were mixed with $2.5 \mu \mathrm{L}$ DNA Gel Loading Dye buffer (Fisher

165 Scientific, USA) and then separated in 1.5\% agarose gel with ethidium bromide (Sigma-Aldrich, 166 USA) in TBE buffer, under $90 \mathrm{~V}$ for $90 \mathrm{~min}$. DNA markers of $100 \mathrm{bp}$ to $1000 \mathrm{bp}$ and concentration 167 of $0.5 \mu \mathrm{g} / \mu \mathrm{l}$ (GeneRuler 100bp, Fermentas, USA) were used to estimate the length of PCR 168 products. The image of electrophoretic separation was archived using the Imagemaster VDS gel 169 reader (Amersham - Pharmacia Biotech, USA) and the Liscap Capture Application ver. 1.0. 170 Electrophoretic gel analysis was performed using GelScan ver. 1.45, (Kucharczyk 171 Electrophoretic Techniques, Poland). The plants identified as having a Grande-1 retrotransposon 172 fragment, which were also fertile and produced seeds, were used for genomic in situ hybridization 173 (GISH).

175 Cytogenetic analysis

176 The seeds of oat, maize, and oat-maize chromosome addition and DH lines were germinated for 177 2-3 days in Petri dishes on a wet filter paper. Seedlings with the root tips of 1.5-2 cm long were 178 immersed in ice-cold water and incubated for $24 \mathrm{~h}$ at $4{ }^{\circ} \mathrm{C}$. The procedure allowed to stop the cell 179 division at metaphase through the spindle degradation, and to increase chromosome condensation. 180 After $24 \mathrm{~h}$, the root tips were fixed in a mixture of pure methanol and glacial acetic acid at a 3:1 181 ratio. The material was kept at $4{ }^{\circ} \mathrm{C}$ for $24 \mathrm{~h}$, and stored in $-20{ }^{\circ} \mathrm{C}$ until used.

182 Excised root tips (about $5 \mathrm{~mm}$ in length) were washed in citrate buffer (pH 4.8) for 15-20 $183 \mathrm{~min}$ and then digested in a solution of 20\% pectinase (Sigma, St Louis, MO, USA), $1 \%$ cellulose 184 (Calbiochem, San Diego, CA, USA) and 1\% cellulase 'Onozuka R-10' (Serva, Heidelberg, 185 Germany) in a citrate buffer at $37^{\circ} \mathrm{C}$ for $2 \mathrm{~h}$. The meristems were dissected from the root tips and 
186 squashed in a drop of $45 \%$ acetic acid. Good quality preparations were frozen on dry ice. After 187 freezing, the coverslips were removed and the slides were air-dried and stored at $4{ }^{\circ} \mathrm{C}$ until 188 required.

In order to discriminate maize chromatin introgressions, the total genomic DNA of the

190

191

192

193

194

195

196

197

198

199

200

201

202

203

204

205

206

207

208

209

210

211

212

213

214

215

216

Maize genomic DNA and 25S rDNA sequences that were used as additional chromosome markers were labeled by nick-translation using the digoxigenin-11-dUTP and rhodamine-5-dUTP (Roche), respectively. The GISH procedure was performed according to the protocol of Hasterok et al. (2006). In order to verify the specificity of the gDNA probe and appropriate hybridization conditions, maize and oat root tips preparations were also used as positive and negative control in GISH, respectively. Hybridization mixture was prepared by adding appropriate volumes of 50\% formamide, $10 \%$ dextran sulfate, $20 \times \mathrm{SSC}$, water, SDS, and labeled DNA probes $(\sim 500 \mathrm{ng} / \mathrm{slide})$. Due to the high phylogenetic distance between oat and maize and related to that low degree of DNA sequence homology, the use of total genomic oat DNA to block non-specific hybridization was not necessary. Posthybridization stringent washes were carried out in $10 \%$ formamide in 0.1 $\times \mathrm{SSC}$ at $42{ }^{\circ} \mathrm{C}$, which is equivalent to $79 \%$ stringency. Immunodetection of digoxigenin-labeled probes was performed according to the standard protocols using FITC-conjugated anti-digoxigenin antibodies (Roche). The rhodamine probes were visualized directly. The preparations were mounted in VectaShield antifade (Vector Laboratories, Inc. Brulingame, CA, USA) containing 2.5 $\mu \mathrm{m} \mathrm{ml}^{-1}$ DAPI (Serva, Heidelberg, Germany). Hybridization signals were visualized and captured using fluorescence microscope Axio Imager Z2 (ZEISS, Germany) equipped with monochromatic camera AxioCam MRm (ZEISS, Germany) and archived by ZEN blue program (ZEISS, Germany). All images were processed uniformly and superimposed using Photoshop CS3 (Adobe).

\section{Statistics}


217 Statistical analysis of embryo formation, DH and OMA lines as well as seeds production was

218 performed using analysis of variance at $p \leq 0.05$ using the STATISTICA 12.0 software package

219 (Stat-Soft, Inc., Tulsa, OK). For comparison of means for seeds number, Duncan's multiple test at 220 the significance level of $p \leq 0.05$ was used. Correlation coefficient for seeds number dependently

221 on maize chromosome/chromatin addition to oat genome was also calculated.

222

223

224

\section{Results}

225

Oat DH lines and oat $\times$ maize hybrids formation

226

Analysis of variance indicated no significant differences between oat genotypes in the production

226 of embryos per emasculated florets and lines per pollinated florets (Table 2). The efficiency of oat

227 lines production by wide crossing with maize is shown in Table 1 . Total of 57515 florets from 80 oat genotypes were pollinated with maize that resulted in development of 2129 embryos (Figure 1A). Average embryo formation frequency per pollinated florets was 3.58\%. Six hundred and one embryos germinated within three weeks of in vitro culturing (28.23\% of all embryos) (Figure 1B). Number of embryos produced by various genotypes varied from 0 to $106(9.69 \%$ embryos per pollinated florets). Only one genotype out of eighty examined did not formed haploid embryos (STH 5.8428). Most embryos per pollinated floret were obtained from the genotypes: STH 4.4690 (9.69\%), STH 4.4606 (7.22\%), STH 4.4586 (6.68\%), STH 5.8425 (6.54\%) and STH 4.8448 $(6.37 \%)$. Even if the genotype did not have the significant effect on the haploid plants production, 15 of 80 genotypes did not develop haploid plants. Total of 210 plants survived the acclimatization to the natural condition (Figure 1C-E). The procedure of chromosome doubling using colchicine reduced the number of obtained lines to 138 . The highest number of lines (16) was obtained from the STH 4.4690 genotype. Plants from seven genotypes completely failed this process. The ploidy of the plants was measured by flow cytometry before and after application of colchicine (Figure 2). Most plants doubled chromosomes number, except plants STH 4.4690 n, STH 4.4690 o, STH 5.8505 b, STH $4.8417 \mathrm{c}$ and STH 5.8540.

Identification of oat $\times$ maize hybrids

A total of 138 oat lines obtained by crossing with maize were tested for the presence of maize chromosomes. The presence of maize chromatin was indicated by amplification of the PCR product $(500 \mathrm{bp})$ generated using primers specific for the maize retrotransposon Grande-1 
248 (GenBank Accession No. X97604; Ananiev et al. 1998). Copies of the Grande-1 are densely 249 dispersed and located on each of the maize chromosomes. The $500 \mathrm{bp}$ PCR product was identified 250 in 66 oat plants. Figure 3 shows the exemplary agarose gel with 500 bp product corresponding to 251 the maize retrotransposon Grande-1. Out of the 66 OMA lines containing maize chromatin, only 25227 were fertile and produced seeds (Table 1). The 20 OMA lines that produced the highest number 253 of seeds were then selected for cytogenetic analysis.

254 The seeds of two out of 20 OMA lines did not germinate. Among the remaining 20 lines, 2558 lines $(40 \%)$ had the character of additive lines, since GISH has detected one or more maize 256 chromosomes in their cells. All of the analyzed plants possessed full complement of oat 257 chromosomes. The number of detected maize chromosomes differed between the OMA lines 258 (Table 1). They were usually smaller than the oat chromosomes and easy to discriminate (Figure 259 260 4). In the plant STH 4.4690f, two pairs of chromosomes of varying size were found (Figure 4A), whereas in STH 5.8504b only one maize chromosome was present (Figure 4B). The majority of OMA lines possessed 2 maize chromosomes similar in size. In most of the lines, the detected chromosomes were labeled uniformly (Figure 4C), however, in some, a banding pattern was visible that can potentially be used for the identification of maize addition (Figure 4D). The banding pattern on both chromosomes in a given line was similar, which might indicate that the added chromosomes are homologs. The presence of six 45S rDNA loci was detected in oat chromosomes (red hybridization signals, Figure 4), but none of the added maize chromosomes in any of the lines carried 45S rDNA locus.

Twenty of the analyzed lines did not possess whole chromosomes of maize, but the introgression of maize chromatin was found in the oat chromosomes. A total of 12-14 hybridization signals for the maize gDNA probe were detected (Figure 5). In all these lines, six of the maize gDNA hybridization signals colocalized with 25S rDNA sequence hybridization signals. In another pair of chromosomes, two strong signals were present in the pericentromeric positions on each of the chromosomes. Additionally, weaker maize gDNA signals were observed in one or two pairs of chromosomes of the lines STH 4.4690d (Figure 5A), and STH 4.4606a (Figure 5C), depending on the metaphase plate, and in one chromosome pair in the case of the line STH 4.4576 (Figure 5B).

The colocalization of the gDNA and 25S rDNA signals may be related to the hybridization 278 of the $25 \mathrm{~S}$ rDNA sequence present in the maize genomic DNA to the same sequence in the oat 
279

280

281

282

283

284

285

286

287

288

289

290

291

292

293

294

295

296

297

298

299

300

301

302

303

304

305

306

307

308

genome. These sequences are highly conservative, hence the presence of these signals in the chromosomes of the analyzed lines. Additional hybridization signals found in 2-3 pairs of chromosomes, depending on the analyzed line, are presumably maize DNA sequences that have been incorporated into the oat chromosomes. Accurate determination of the origin of these sequences requires further analysis.

Vigor of DH and OMA lines in their effectiveness in seeds production

The progeny of oat-maize hybrids showed some differences in morphology. Five of 66 hybrids were shorter in height, grassy type without panicles (Figure 1G). Three of them had only a few short shoots with small panicles (Figure 1F). Leaves' blades color and panicle shape were similar to their oat parent.

Analysis of variance showed significant variation in fertility in dependence on the addition of maize chromosomes to the oat genome (Table 1). OMA plants produced significantly less seeds than DH lines. Negative correlation coefficient (-0.279) for seeds production dependently on the maize chromosomes/chromatin added to the oat genome was observed.

Sixty-three fertile DH lines out of 72 which did not have an addition of maize chromosomes or chromatin produced seeds (Table 2). Nine DH lines belonging to various genotypes did not produce seeds. The number of seeds was from 1 to 343, dependently on the genotype. In total, 3758 seeds were produced. The highest number of seeds (343 in total) was produced by the STH 5.8429 genotype.

Twenty-seven OMA lines (from 66 identified) were fertile and produced seeds ranging in number from 1 - 102 (Table 2). In total, 613 seeds were produced by OMA lines. As for DH lines, the number of seeds produced by OMA lines depended on genotype, however nearly $41 \%$ of OMA plants were sterile. The differences in the seed production were not dependent on the number of chromosomes added to the oat genome or introgression of chromosome fragments to the oat chromosomes. OMA lines with the addition of whole chromosomes produced seeds as well as the ones with the introgression of fragments of maize chromosomes. All DH and OMA lines were fertile and produced seeds in the subsequent generation.

\section{Discussion}


309 In wide hybridization in Poaceae, the complete or incomplete chromosomes elimination of one of

310 the parent occur (Laurie and Bennett 1986, 1988; Laurie 1989; Rines and Dahleen 1990). There

311 are several reports concerning the mechanisms of this process. In wheat $\times$ maize hybrids, Mochida

312 et al. (2004) found partial addition of the spindle microtubules to the centromeres of maize. In

313 wheat $\times$ maize crosses, haploid wheat plants are obtained as a effect of complete elimination of

314 the maize chromosomes prior to embryo rescue. In a wheat $\times$ pearl millet hybrids cells, Gernand

315 et al. (2005) detected delaying pearl millet chromosomes in anaphase and nuclear discarding of

316 pearl millet chromatin in interphase. In the same wheat $\times$ pearl millet hybrids, Ishii et al. (2010)

317 noticed chromosomes breaking and lack of consistency of the pearl millet chromosomes.

318 The wide-cross combinations between various species of Triticeae as the female and a wide

319 variety of Panicoideae species including sorghum and pearl millet as the male, showed a similar

320 pattern of hybrid zygote formation with uniparental loss of the donor pollen chromosomes during

321 subsequent embryo development (Rines et al. 2005). Chromosomes elimination was reported in

322 crosses of wheat (female) and Hordeum bulbosum L. with maize (Zea mays), pearl millet

323 (Pennisetum glaucum), sorghum (Sorghum bicolor), Coix lacryma-jobi, and Imperata cylindrica

324 (Barclay 1975; Laurie and Bennett 1986, 1988, 1989; Laurie 1989; Inagaki and Mujeeb-Kazi 1995;

325 Mochida and Tsujimoto 2001; Komeda et al. 2007, Ishii et al. 2010). The cells of H. bulbosum

326 fertilize the cells of wheat typically, but in hybrid embryogenesis the chromosomes of H. bulbosum

327 are progressively extruded from the hybrid nucleus in the anaphase-telophase transition. The

328 process is proceeded by micronuclei and condensed chromosomes formation (Zenkteler and Straub 329 1979).

Genomic in situ hybridization (GISH) is a modification of fluorescence in situ hybridization (FISH) in which the total genomic DNA of a given species is used as a probe to hybridize with the complementary DNA in a cytogenetic preparation (Schwarzacher 2003). This technique allows for the genome-specific chromosome labeling in the cells of allopolyploid or hybrid species. It has been widely used in plant studies to identify putative parental genomes in the interspecific or intergeneric hybrids or allopolyploids (for the review see Chester et al. 2010; Silva and Souza, 2013), to study the evolution of polyploid genomes (Song et al. 1995; Gaeta et al. 2007; Majka et al. 2018; Tan et al. 2017), or to detect the introgression of alien chromatin (Schneider et al. 2005; Tan et al. 2005). It has become also a valuable tool to analyze the meiotic 
340

341

342

343

344

345

346

347

348

349

350

351

352

353

354

355

356

357

358

359

360

361

362

363

364

365

366

367

368

369

370

as translocation (Kruppa et al. 2013), addition (Molnar-Lang et al. 2000; Ji and Chetelat 2007), or substitution (Pan et al. 2017) lines.

In the GISH-based studies, an excess of unlabeled blocking genomic DNA derived from the other parental species is often necessary in order to avoid non-specific cross-hybridization. Alternatively, the genomic DNAs of all parental species can be labeled differentially and hybridized simultaneously to the chromosomes of a hybrid/allopolyploid. In the studies of the genus Paphiopedilum, various ratios of blocking DNA has been applied in order to distinguish between the component genomes of the analyzed hybrid species, depending on the phylogenetic distance between the putative parents (Lee et al. 2011). In the case of a very close phylogenetic relationship between the parental species, even very high ratios of the blocking DNA are often not sufficient to distinguish the chromosomes of each donor genome (Xiong et al. 2006, Lee et al. 2011). On the other hand, in the intergeneric hybrids and allopolyploids, GISH can be applied successfully even without blocking DNA (Tang et al. 2011). In our studies, the large genetic distance between maize and oat allowed us to specifically label and distinguish maize chromatin with no blocking DNA from oat. It should be noted though, that the ease of discriminating the genomes of genetically distant species is usually coupled with difficulty in generating the crosses between them.

Although the GISH results allow us to unambiguously detect maize chromatin, the information provided by this method is not sufficient to identify which particular maize chromosome was added to the oat genome. The observation that some chromosomes in were labeled uniformly, whereas other displayed clearly a banding hybridization pattern, indicates that different maize chromosomes were retained in various OMA lines. The banding pattern probably reflects varying distribution of highly repetitive sequences in the chromosomes of maize since these sequences usually constitute the most of genomic DNA used as a probe. In the studies by Rines et al. (2009) the identification of the maize chromosomes in the produced OMA lines was achieved using maize chromosome-specific simple sequence repeat (SSR) markers. An alternative, cytogenetic approach would require performing a FISH experiment with several different types of repetitive sequences as probes, labeled with different fluorophores and hybridized simultaneously in order to create unique banding pattern on added maize chromosomes. Comparing the results with the FISH on maize as a control would allow to discover the identity of the chromosome addition. Such multicolor-FISH method utilizing tandemly repeated DNA sequences has been 
371 applied before to maize chromosomes and permitted to distinguish each of the 10 chromosomes

372 (Kato et al. 2004).

373 Oat (Avena sativa L.) haploid plants can be induced by hybridization either with maize

374 (Rines et al. 1996; Sidhu et al. 2006; Marcińska et al. 2013; Nowakowska et al. 2015; Warchoł et 375 al. 2016) or with pearl millet (Rines et al. 1997; Ishii et al. 2013). In oat and maize crosses, 376 sometimes it happens that some maize chromosomes are not extruded during embryogenesis, and 377 they ultimately stabilized and acted as oat chromosomes in mitosis (Okagaki et al. 2001). About 378 one-third of the plants obtained from oat $\times$ maize crosses contain one or more maize chromosomes 379 added to a complete set of oat chromosomes (Rines et al. 2005, 2009). Over the past few years, all 380 ten maize chromosomes have been recovered as single chromosome additions to a haploid oat 381 complement.

Riera-Lizarazu et al. (1996) after oat pollination by maize obtained 30 plants (one third of 383 all plants) with retained 1 to 4 maize chromosomes, as a result of partial maize chromosomes elimination. Hybrid plants, in which some cells contained maize chromosomes and other did not, also were found. Authors explained that maize chromosomes elimination in crosses between oat and maize is more gradual than e.g. in wheat and maize. In the study by Kynast et al. (2012), hybrids of oat and maize were euhaploids with a complete set of oat chromosomes without maize chromosomes, and aneuhaploids with a complete set of oat chromosomes and various number of retained maize chromosomes. Some of these haploids formed seeds to fifty percent of their spikelets. However, little is known about hybrids fertility Kynast et al. (2012) noticed that the total seeds of $F_{1}$ hybrids generation with maintained maize chromosomes seemed to be meaningfully influenced by the number of retained maize chromosomes as well as by interaction of maize chromosomes with oat chromosomes. Also the environmental conditions during $\mathrm{F}_{1}$ hybrids cultivation appeared to had an impact on fertility. Based on chromosome observations and marker analyses in $\mathrm{F}_{1}$ generation of oat $\times$ pearl millet crosses, Ishii et al. (2015), showed that the seedlings were full hybrids with all oat and pearl millet chromosomes. Although the hybrids of oat with pearl millet developed, they became necrotic in light condition.

In our experiment we found $53 \%$ of haploid plants and $47 \%$ of hybrids obtained after oat 399 $\times$ maize crosses. The hybrids retained 1 to 4 maize chromosomes or fragments of maize chromosomes added to the oat chromosomes. Nearly $41 \%$ of hybrids was infertile. In the study 401 by Kynast and Riera-Lizarazu (2011), offspring of oat $\times$ maize consisted of 50-66\% haploid oat 
402 plants and 34-50\% partial hybrids. Haploid oat and partial hybrids with 1-3 maize chromosomes 403 were incompletely fertile. Partial hybrids with more than 3 maize chromosomes had were smaller 404 than haploid plants and sterile.

405 In our experiment seeds production depended on oat genotype and retained maize 406 chromosomes in oat genome. Among 72 oat DH lines, 9 did not produce seeds, whereas in the 407 group of 66 hybrids - 39 were infertile. Seeds produced even hybrid with retained 4 maize 408 chromosomes. The hybrids also showed differences in morphology. Some of them were visibly 409 shorter than maternal and DH plants. In contrast to Kynast et al. (2001), they did not show 410 differences in the color of leaf blade and panicle shape.

411

412

413

414

415

416

417

418

419

420

421

422

423

424

425

426

427

428

429

Dong Z, Yu J, Li H, Huang W, Xu L, Zhao Y, Zhang T, Xu W, Jiang J, Su Z, Jin W (2018)

430

431

Transcriptional and epigenetic adaptation of maize chromosomes in Oat-Maize addition lines. Nucleic Acids Research 46(10):5012-5028 
432 Doyle JJ, Doyle JL (1987) A rapid DNA isolation procedure for small quantities of fresh leaf

433

434

435

436

437

438

439

440

441

442

443

444

445

446

447

448

449

450

451

452

453

454

455

456

457

458

459

460 tissue. Phytochem Bull 19:11-15

Dunwell JM (2010) Haploids in flowering plants: origins and exploitation. Plant Biotechnol J $8: 377-424$

Gaeta RT, Pires JC, Iniguez-Luy F, Leon E, Osborn TC. (2007) Genomic changes in resynthesized Brassica napus and their effect on gene expression and phenotype. Plant Cell 19:34033417

Garcia N, Zhang W, Wu Y, Messing J (2015) Evolution of gene expression after gene amplification. Genome Biology and Evolution 7(5):1303-1312

Gernand D, Bruss C, Houben A, Kumlehn J, Matzk F, Prodanovic S, Rubtsova M, Rutten T, Varshney A (2005) Uniparental chromosome elimination at mitosis and interphase in wheat and pearl millet crosses involves micronucleus formation, progressive heterochromatinization, and DNA fragmentation. Plant Cell 17:2431-2438

Hasterok R, Marasek A, Donnison IS, Armstead I, Thomas A, King IP, Wolny E, Idziak D, Draper J, Jenkins G (2006) Alignment of the genomes of Brachypodium distachyon and temperate cereals and grasses using bacterial artificial chromosome landing with fluorescence in situ hybridization. Genetics 173:349-362

Inagaki M, Mujeeb-Kazi A (1995) Comparison of polyhaploid production frequencies in crosses of hexaploid wheat with maize, pearl millet and sorghum. Breed Sci. 45:157-161

Ishii T, Tanaka H, Eltayeb AE, Tsujimoto H (2013) Wide hybridization between oat and pearl millet belonging to different subfamilies of Poaceae. Plant Reprod 26:25-32

Ishii T, Ueda T, Tanaka H, Tsujimoto H (2010) Chromosome elimination by wide hybridization between Triticeae or oat plant and pearl millet: pearl millet chromosome dynamics in hybrid embryo cells. Chromosome Res 18:821-831

Ishii T, Sunamura N, Matsumoto A, Eltayeb AE, Tsujimoto H (2015) Preferential recruitment of the maternal centromere-specific histone $\mathrm{H} 3(\mathrm{CENH} 3)$ in oat (Avena sativa $\mathrm{L}$.) $\times$ pearl millet (Pennisetum glaucum L.) hybrid embryos. Chromosome Res. 23(4):709-718

Ji Y, Chetelat RT (2007) GISH analysis of meiotic chromosome pairing in Solanum lycopersicoides introgression lines of cultivated tomato. Genome 50:825-833 
461 Jin W, Melo JR, Nagaki K, Talbert PB, Henikoff S, Dawe RK, Jiang J (2004) Maize centromeres:

462

463

464

465

466

467

468

469

470

471

472

473

474

475

476

477

478

479

480

481

482

483

484

485

486

487

488

489
Organization and functional adaptation in the genetic background of oat. Plant Cell 16: 571-581.

Karimi-Ashtiyani R, Ishii T, Niessen M, Stein N, Heckmann S, Gurushidze M, BanaeiMoghaddam AM, Fuchs J, Schubert V, Koch K, Weiss O, Demidov D, Schmidt K, Kumlehn J, Houben A (2015) Point mutation impairs centromeric CENH3 loading and induces haploid plants. Proc Natl Acad Sci USA 112(36):11211-11216

Kasha KJ, Kao KN (1970) High frequency haploid production in barley (Hordeum vulgare L.). Nature 225: 874-876

Kato A, Lamb JC, Birchler JA (2004) Chromosome painting using repetitive DNA sequences as probes for somatic chromosome identification in maize. Proc Natl Acad Sci USA $101: 13554-13559$

Kelliher T, Starr D, Wang W, McCuiston J, Zhong H, Nuccio ML, Martin B (2016) Maternal haploids are preferentially induced by CENH3-tailswap transgenic complementation in maize. Front. Plant Sci. 7:414

Komeda N, Chaudhary HK, Suzuki G, Mukai Y (2007) Cytological evidence for chromosome elimination in wheat $\times$ Imperata cylindrica hybrids. Genes Genet Syst 82:241-248

Koumbaris GL, Bass HW (2003) A new single-locus cytogenetic mapping system for maize (Zea mays L.): overcoming FISH detection limits with marker-selected sorghum (S. propinquum L.) BAC clone. Plant J 35:647-659

Kowles RV, Walch MD, Minnerath JM, Bernacchi CJ, Stec AO, Rines HW, Phillips RL (2008) Expression of $\mathrm{C} 4$ photosynthetic enzymes in oat-maize chromosome addition lines. Maydica 53: 69-78

Kruppa K, Sepsi A, Szakacs E, Roder MS, Molnar-Lang M (2013) Characterization of a 5HS7DS.7DL wheat-barley translocation line and physical mapping of the 7D chromosome using SSR markers. J Appl Genet 54:251-258

Kynast RG, Davis DW, Phillips RL, Rines HW (2012) Gamete formation via meiotic nuclear restitution generates fertile amphiploid F1 (oat $\times$ maize) plants. Sex Plant Reprod 25:111122 
490

491

492

493

494

495

496

497

498

499

500

501

502

503

504

505

506

507

508

509

510

511

512

513

514

515

516

517

518

519

Kynast RG, Okagaki RJ, Rines HW. Phillips R.L (2002) Maize individualized chromosome and derived radiation hybrid lines and their use in functional genomics. Funct Integr Genomics 2: $60-69$

Kynast RG, Riera-Lizarazu O (2011) Development and use of oat-maize chromosome additions and radiation hybrids. James A. Birchler (ed.), Plant Chromosome Engineering: Methods and Protocols, Methods in Molecular Biology, vol. 701: 259-284

Kynast RG, Riera-Lizarazu O, Vales MI, Okagaki RJ, Maquieira SB, Chen G, Ananiev EV, Odland WE, Russell CD, Stec AO, Livingston SM, Zaia HA, Rines HW, Phillips RL (2001) A complete set of maize individual chromosome additions to the oat genome. Plant Physiol 125: 1216-1227

Laurie DA (1989) The frequency of fertilization in wheat $\times$ pearl millet crosses. Genome, 32:1063-1067

Laurie DA, Bennett MD (1986) Wheat × maize hybridization. Can J Genet Cytol 28:313-316

Laurie DA, Bennett MD (1988) Cytological evidence for fertilization in hexaploid wheat $\times$ sorghum crosses. Plant Breed 100:73-82

Laurie DA, Bennett MD (1989) The timing of chromosome elimination in hexaploid wheat $\times$ maize crosses. Genome 32:953-961

Lee YI, Chang FC, Chung MC (2011) Chromosome pairing affinities in interspecific hybrids reflect phylogenetic distances among lady's slipper orchids (Paphiopedilum). Ann Bot 108:113-121

Liu D, Zhang H, Zhang L, Yuan Z, Hao M, Zheng Y (2014) Distant Hybridization: A Tool for Interspecifi c Manipulation of Chromosomes. In: A. Pratap and J. Kumar (eds.), Alien Gene Transfer in Crop Plants, Volume 1: 25 Innovations, Methods and Risk Assessment

Majka J, Zwierzykowski Z, Majka M, Kosmala A (2018) Karyotype reshufflings of Festuca pratensis $\mathrm{x}$ Lolium perenne hybrids. Protoplasma 255(2): 451-458

Maheshwari S, Tan EH, West A, Franklin FCH, Comai L, Chan SWL (2015) Naturally occurring differences in CENH3 affect chromosome segregation in zygotic mitosis of hybrids. PLoS Genet. 11:e1004970

Maquieira SB (1997) Production and characterization of plants from oat $\times$ maize and oat $\times$ pearl millet. MS Thesis, University of Minnesota, St. Paul 
520 Marcińska I, Nowakowska A, Skrzypek E, Czyczyło-Mysza I (2013) Production of double 521 haploids in oat (Avena sativa L.) by pollination with maize (Zea mays L.). Cent Eur J Biol

522

523

524

525

526

527

528

529

530

531

532

533

534

535

536

537

538

539

540

541

542

543

544

545

546

547

548

549

550

\section{8:306-313}

Mochida K, Tsujimoto H (2001) Production of wheat double haploids by pollination with Job's Tears ( Coix lacrymajobi L.). Heredity 92:81-83

Molnar-Lang M, Linc G, Logojan A, Sutka J (2000) Production and meiotic pairing behaviour of new hybrids of winter wheat (Triticum aestivum) $\mathrm{x}$ winter barley (Hordeum vulgare). Genome 43:1045-1054

Murashige T, Skoog F (1962) A revised medium for rapid growth and bioassays with tobacco tissue cultures. Physiol Plant 15:473-497

Noga A, Skrzypek E, Warchoł M, Czyczyło-Mysza I, Dziurka K, Marcińska I, Juzoń K, Warzecha T, Sutkowska A, Nita Z, Werwinska K (2016) Conversion of oat (Avena sativa L.) haploid embryos into plants in relation to embryo developmental stage and regeneration media. In Vitro Cellular \& Developmental Biology-Plant, 52:590-597

Nowakowska A, Skrzypek E, Marcińska I, Czyczyło-Mysza I, Dziurka K, Juzoń K, Cyganek K, Warchol M (2015) Application of chosen factors in the wide crossing method for the production of oat doubled haploids. Open Life Sci 10:112-118

Okagaki RJ, Kynast RG, Livingston SM, Russell CD, Rines HW, Phillips RL (2001) Mapping maize sequences to chromosome using oat-maize chromosome addition materials. Plant Physiol. 125:1228-1235

Pan C, Li Q, Lu Y, Zhang J, Yang X, Li X, Li L, Liu W (2017) Chromosomal localization of genes conferring desirable agronomic traits from Agropyron cristatum chromosome 1P. PLoS One 12 , e0175265.

Ravi M, Chan SWL (2010) Haploid plants produced by centromere-mediated genome elimination. Nature 464:615-618

Riera-Lizarazu O, Rines HW, Phillips RL (1996) Cytological and molecular characterization of oat $\times$ maize partial hybrids. Theor Appl Genet. 93:123-135

Rines HW, Dahleen LS (1990) Haploid oat plants produced by application of maize pollen to emasculated oat florets. Crop Sci. 30:1073-1078

Rines HW, Phillips RL, Kynast RG, Okagaki RJ, Galatowitsch MW, Huettl PA, Stec AO, Jacobs MS, Suresh J, Porter HL, Walch MD, Cabral CB (2009) Addition of individual 
551

552

553

554

555

556

557

558

559

560

561

562

563

564

565

566

567

568

569

570

571

572

573

574

575

576

577

578

579

580

chromosomes of maize inbreds B73 and Mo17 to oat cultivars Starter and Sun II: maize chromosome retention, transmission, and plant phenotype. Theor Appl Genet 119:12551264

Rines HW, Phillips RL, Kynast RG, Okagaki RJ, Odland WE, Stec AO, Jacobs MS, Granath SR (2003) Maize chromosome additions and radiation hybrids in oat and their use in dissecting the maize genome. In: Tuberosa R., Phillips R.L., Gale M. (eds.), Proceedings of the International Congress "In the Wake of the Double Helix: From the Green Revolution to the Gene Revolution”, 27-31 May 2003, Bologna, Italy, 427-441

Rines HW, Riera-Lizarazu O, Maquieira SB, Phillips RL (1996) Wide crosses for haploids. In: Scoles G, Rossnagel B, editors. Proceedings of the Fifth International Oat Conference and Eighth International Barley Genetic Symposium, Saskatoon, Saskatchewan, Canada. pp. $207-212$

Rines HW, Riera-Lizarazu O, Nunez VM, Davis DM, Phillips RL (1997) Oat haploids from anther culture and from wide hybridizations. In: Jain SM, Sopory SK, Veilleux RE, editors. In Vitro Production of Haploids in Higher Plants 4. Dordrecht, The Netherlands: Kluwer Academic Publishers; pp. 205-221

Schneider A, Linc G, Molnar I, Molnar-Lang M (2005) Molecular cytogenetic characterization of Aegilops biuncialis and its use for the identification of 5 derived wheat-Aegilops biuncialis disomic addition lines. Genome 48:1070-1082

Schwarzacher T (2003) DNA, chromosomes, and in situ hybridization. Genome 46:953-962

Sidhu PK, Howes NK, Aung T, Zwer PK, Davies PA (2006) Factors affecting oat haploid production following oat $\times$ maize hybridization. Plant Breed 125:243-247

Silva GS, Souza MM (2013) Genomic in situ hybridization in plants. Genet Mol Res 12:29532965

Song K, Lu P, Tang K, Osborn TC (1995) Rapid genome change in synthetic polyploids of Brassica and its implications for polyploid evolution. Proc Natl Acad Sci USA 92: 77197723

Tan C, Cui C, Xiang Y, Ge X, Li Z (2017) Development of Brassica oleracea-nigra monosomic alien addition lines: genotypic, cytological and morphological analyses. Theor Appl Genet 130: 2491-2504 
581 Tan G, Jin H, Li G, He R, Zhu L, He G (2005) Production and characterization of a complete set

582 of individual chromosome additions from Oryza officinalis to Oryza sativa using RFLP 583 and GISH analyses. Theor Appl Genet 111:1585-1595

584 Tang F, Wang H, Chen S, Chen F, Liu Z, Fang W (2011) Intergeneric hybridization between 585 Dendranthema nankingense and Tanacetum vulgare. Scientia Horticulturae 132:1-6

586 Topp CN, Okagaki RJ, Melo JR, Kynast RG, Phillips RL, Dawe RK (2009) Identification of a 587 maize neocentromere in an oat-maize addition line. Cytogenet Genome Res 124:228-238

588 Wang K, Wu Y, Dawe K, Jiang J (2014) Maize centromers expand and adopt a uniform size in the 589 genetic background of oat. Genome Research 24:107-116

590 Warchoł M, Skrzypek E, Nowakowska A, Barcińska I, Czyczyło-Mysza I, Dziurka K, Juzoń K, 591 Cyganek K (2016) The effect of auxin and genotype on the production of Avena sativa L. 592 593 594 595 596 doubled haploids lines. Plant Growth Regul 78:155-165

Xiong ZY, Tan GX, He GY, He GC, Song YC (2006) Cytogenetic comparisons between A and G genomes in Oryza using genomic in situ hybridization. Cell Research 16:260-266

Zenkteler M, Straub J (1979) Cytoembryological studies on the process of fertilization and the development of haploid embryos of Triticum aestivum L. $(2 \mathrm{n}=47)$ after crossing with Hordeum bulbosum (2n=14). Zeitschrift fur Pflanzenzüchtung 82: 32-44

Zhuang JJ, Xu J (1983) Increasing differentiation frequencies in wheat pollen callus. In: $\mathrm{Hu} \mathrm{H}$, Vega MR (eds) Cell and Tissue Culture Techniques for Cereal Crop Improvement. Science 600 Press, Beijing, p 431

601 Zwierzykowski Z, Zwierzykowska E, Taciak M, Jones N, Kosmala A, Krajewski P (2008) 602 Chromosome pairing in allotetraploid hybrids of Festuca pratensis x Lolium perenne 603 revealed by genomic in situ hybridization (GISH). Chromosome Res 16:575-585 


\section{Table $\mathbf{1}$ (on next page)}

The influence of oat (Avena sativa L.) genotype on the efficiency of haploid embryos, plants and seeds production using wide crossing with maize (Zea mays L.)

Significant differences between oat lines according to Duncan's test, $p \leq 0.05$, are marked with different letters 


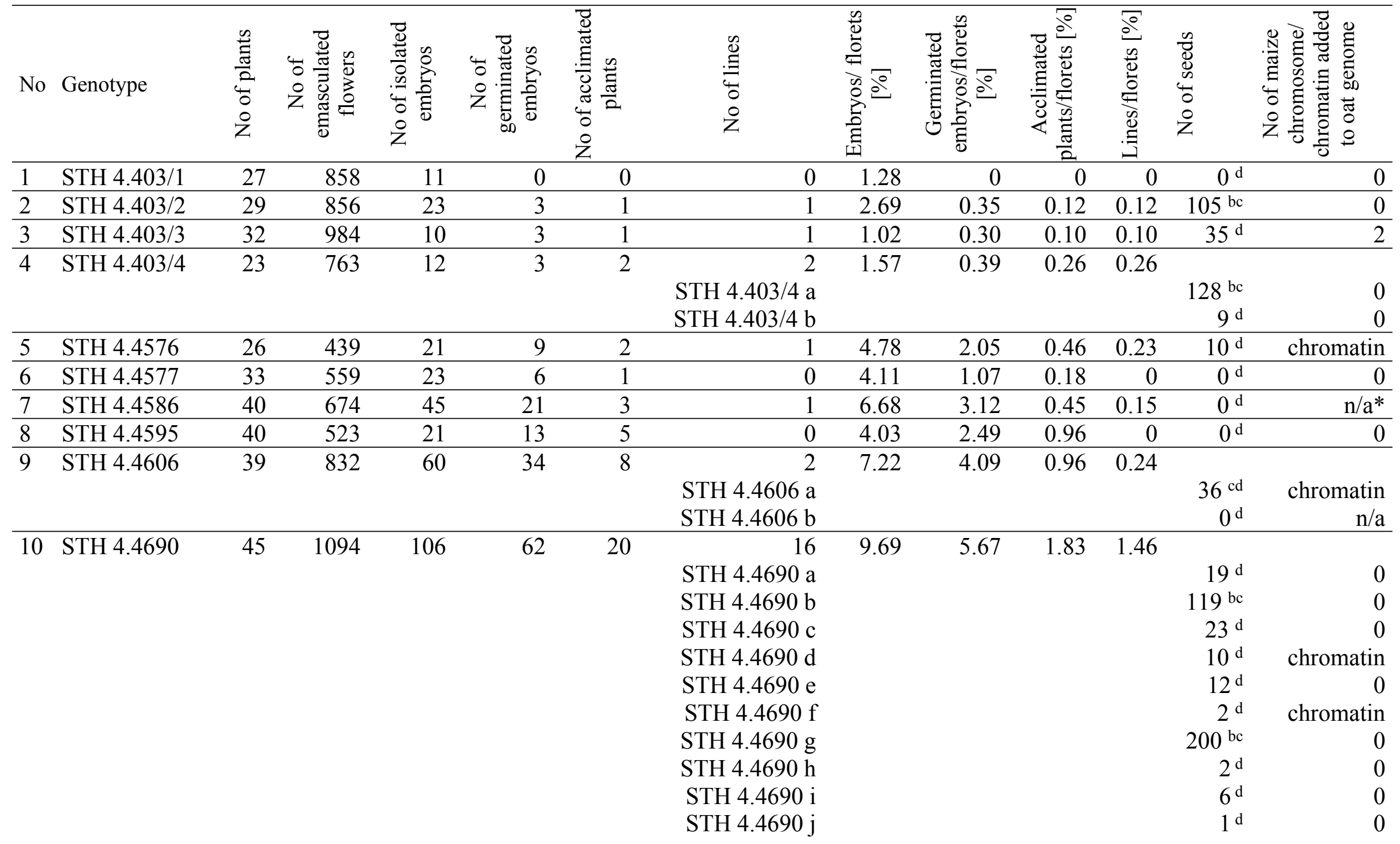




\begin{tabular}{|c|c|c|c|c|c|c|c|c|c|c|c|c|}
\hline & & & & & & $\begin{array}{l}\text { STH } 4.4690 \mathrm{k} \\
\text { STH } 4.46901 \\
\text { STH } 4.4690 \mathrm{~m} \\
\text { STH } 4.4690 \mathrm{n} \\
\text { STH } 4.4690 \mathrm{o} \\
\text { STH } 4.4690 \mathrm{p}\end{array}$ & & & & & $\begin{array}{l}1^{d} \\
0^{d} \\
0^{d} \\
0^{d} \\
0^{d} \\
1^{d}\end{array}$ & $\begin{array}{r}0 \\
0 \\
\mathrm{n} / \mathrm{a} \\
\mathrm{n} / \mathrm{a} \\
\mathrm{n} / \mathrm{a} \\
4\end{array}$ \\
\hline 11 STH 4.4729 & 36 & 927 & 33 & 4 & 2 & 1 & 3.56 & 0.43 & 0.22 & 0.11 & $0^{d}$ & $\mathrm{n} / \mathrm{a}$ \\
\hline 12 STH 4.4731 & 35 & 776 & 33 & 13 & 5 & $\begin{array}{l}4 \\
\text { STH 4.4731 a } \\
\text { STH 4.4731 b } \\
\text { STH 4.4731 c } \\
\text { STH 4.4731 d }\end{array}$ & 4.25 & 1.68 & 0.64 & 0.52 & $\begin{array}{r}911^{\mathrm{bc}} \\
14^{\mathrm{d}} \\
14^{\mathrm{d}} \\
6^{\mathrm{d}} \\
\end{array}$ & $\begin{array}{l}0 \\
0 \\
0 \\
0\end{array}$ \\
\hline 13 STH 4.4740 & 33 & 717 & 38 & 10 & 3 & $\begin{array}{r}2 \\
\text { STH 4.4740 a } \\
\text { STH 4.4740 b } \\
\end{array}$ & 5.30 & 1.39 & 0.42 & 0.28 & $\begin{array}{r}20^{\mathrm{d}} \\
57^{\mathrm{bcd}}\end{array}$ & $\begin{array}{l}0 \\
0\end{array}$ \\
\hline 14 STH 4.4742 & 22 & 647 & 34 & 17 & 7 & $\begin{array}{l}4 \\
\text { STH 4.4742 a } \\
\text { STH 4.4742 b } \\
\text { STH 4.4742 c } \\
\text { STH 4.4742 d }\end{array}$ & 5.26 & 2.63 & 1.08 & 0.62 & $\begin{array}{r}77^{\mathrm{bc}} \\
222^{\mathrm{b}} \\
5^{\mathrm{d}} \\
1^{\mathrm{d}} \\
\end{array}$ & $\begin{array}{r}\text { chromatin } \\
0 \\
0 \\
\text { chromatin } \\
\end{array}$ \\
\hline 15 STH 4.8402 & 36 & 626 & 31 & 8 & 1 & 0 & 4.95 & 1.28 & 0.16 & 0 & $0^{d}$ & 0 \\
\hline 16 STH 4.8411 & 28 & 623 & 27 & 9 & 1 & 1 & 4.33 & 1.44 & 0.16 & 0.16 & $165 \mathrm{bc}$ & \\
\hline 17 STH 4.8417 & 26 & 648 & 28 & 10 & 4 & $\begin{array}{l}4 \\
\text { STH 4.8417 a } \\
\text { STH 4.8417 b } \\
\text { STH 4.8417 c } \\
\text { STH 4.8417 d }\end{array}$ & 4.32 & 1.54 & 0.62 & 0.62 & $\begin{array}{r}0^{d} \\
0^{d} \\
0^{d} \\
10^{d} \\
\end{array}$ & $\begin{array}{r}\mathrm{n} / \mathrm{a} \\
\mathrm{n} / \mathrm{a} \\
\mathrm{n} / \mathrm{a} \\
0\end{array}$ \\
\hline 18 STH 4.8432 & 34 & 681 & 26 & 4 & 1 & 1 & 3.82 & 0.59 & 0.15 & 0.15 & $0^{d}$ & 0 \\
\hline 19 STH 4.8435 & 35 & 653 & 29 & 5 & 1 & 0 & 4.44 & 0.77 & 0.15 & 0 & $0^{d}$ & 0 \\
\hline 20 STH 4.8437 & 30 & 602 & 35 & 10 & 5 & $\begin{array}{r}2 \\
\text { STH 4.8437 a } \\
\text { STH 4.8437 b }\end{array}$ & 5.81 & 1.66 & 0.83 & 0.33 & $\begin{array}{l}4^{\mathrm{d}} \\
0^{\mathrm{d}}\end{array}$ & $\begin{array}{r}0 \\
\mathrm{n} / \mathrm{a}\end{array}$ \\
\hline 21 STH 4.8442 & 33 & 826 & 45 & 9 & 3 & 1 & 5.45 & 1.09 & 0.36 & 0.12 & $0^{d}$ & $\mathrm{n} / \mathrm{a}$ \\
\hline
\end{tabular}




\begin{tabular}{|c|c|c|c|c|c|c|c|c|c|c|c|c|c|}
\hline 22 & STH 4.8448 & 29 & 518 & 33 & 11 & 2 & 1 & 6.37 & 2.12 & 0.39 & 0.19 & $0^{d}$ & $\mathrm{n} / \mathrm{a}$ \\
\hline \multirow[t]{3}{*}{23} & STH 4.8456/1 & 51 & 1019 & 29 & 3 & 2 & 2 & 2.85 & 0.29 & 0.20 & 0.20 & & \\
\hline & & & & & & & STH $4.8456 / 1 \mathrm{a}$ & & & & & $7^{d}$ & 0 \\
\hline & & & & & & & STH $4.8456 / 1 \mathrm{~b}$ & & & & & $6^{d}$ & 0 \\
\hline \multirow[t]{8}{*}{24} & STH 4.8456/2 & 45 & 1043 & 27 & 10 & 7 & 7 & 2.59 & 0.96 & 0.67 & 0.67 & & \\
\hline & & & & & & & STH $4.8456 / 2 \mathrm{a}$ & & & & & $80 \mathrm{bc}$ & 0 \\
\hline & & & & & & & STH $4.8456 / 2 \mathrm{~b}$ & & & & & $39^{\mathrm{cd}}$ & 0 \\
\hline & & & & & & & STH $4.8456 / 2 \mathrm{c}$ & & & & & $17^{\mathrm{d}}$ & 0 \\
\hline & & & & & & & STH $4.8456 / 2 \mathrm{~d}$ & & & & & $11^{\mathrm{d}}$ & 0 \\
\hline & & & & & & & STH $4.8456 / 2 \mathrm{e}$ & & & & & $53^{\mathrm{cd}}$ & chromatin \\
\hline & & & & & & & STH $4.8456 / 2 \mathrm{f}$ & & & & & $1^{\mathrm{d}}$ & chromatin \\
\hline & & & & & & & STH $4.8456 / 2 \mathrm{~g}$ & & & & & $0^{d}$ & 0 \\
\hline 25 & STH 4.8457/1 & 42 & 887 & 30 & 1 & 1 & 1 & 3.38 & 0.11 & 0.11 & 0.11 & $53^{\mathrm{cd}}$ & 0 \\
\hline \multirow[t]{6}{*}{26} & STH 4.8457/2 & 47 & 1141 & 47 & 8 & 5 & 5 & 4.12 & 0.70 & 0.44 & 0.44 & & \\
\hline & & & & & & & STH $4.8457 / 2 \mathrm{a}$ & & & & & $105^{\mathrm{bc}}$ & 0 \\
\hline & & & & & & & STH $4.8457 / 2$ b & & & & & $0^{\mathrm{d}}$ & 0 \\
\hline & & & & & & & STH $4.8457 / 2 \mathrm{c}$ & & & & & $0^{d}$ & $\mathrm{n} / \mathrm{a}$ \\
\hline & & & & & & & STH $4.8457 / 2 \mathrm{~d}$ & & & & & $0^{d}$ & $\mathrm{n} / \mathrm{a}$ \\
\hline & & & & & & & STH $4.8457 / 2 \mathrm{e}$ & & & & & $0^{d}$ & $\mathrm{n} / \mathrm{a}$ \\
\hline 27 & STH 4.8459 & 20 & 286 & 13 & 2 & 1 & 0 & 4.55 & 0.70 & 0.35 & 0 & $0^{d}$ & 0 \\
\hline 28 & STH 5.451/1 & 25 & 627 & 10 & 2 & 0 & 0 & 1.59 & 0.32 & 0 & 0 & $0^{d}$ & 0 \\
\hline & STH 5.451/2 & 23 & 614 & 17 & 5 & 3 & 2 & 2.77 & 0.81 & 0.49 & 0.33 & & \\
\hline & & & & & & & STH 5.451/2 & & & & & $0^{d}$ & $\mathrm{n} / \mathrm{a}$ \\
\hline & & & & & & & STH 5.451/2 & & & & & $0^{d}$ & $\mathrm{n} / \mathrm{a}$ \\
\hline 30 & STH 5.451/3 & 21 & 509 & 6 & 4 & 1 & 1 & 1.18 & 0.79 & 0.20 & 0.20 & $0^{d}$ & 0 \\
\hline 31 & STH 5.451/4 & 21 & 518 & 9 & 1 & 0 & 0 & 1.74 & 0.19 & 0 & 0 & $0^{d}$ & 0 \\
\hline 32 & STH 5.8046 & 2 & 77 & 2 & 0 & 0 & 0 & 2.60 & 0 & 0 & 0 & $0^{d}$ & 0 \\
\hline \multirow[t]{6}{*}{33} & STH 5.8421 & 35 & 998 & 32 & 8 & 7 & 7 & 3.21 & 0.80 & 0.70 & 0.70 & & \\
\hline & & & & & & & STH $5.8421 \mathrm{a}$ & & & & & $183 \mathrm{bc}$ & 0 \\
\hline & & & & & & & STH $5.8421 \mathrm{~b}$ & & & & & $24^{\mathrm{d}}$ & 0 \\
\hline & & & & & & & STH $5.8421 \mathrm{c}$ & & & & & $20^{d}$ & 0 \\
\hline & & & & & & & STH $5.8421 \mathrm{~d}$ & & & & & $102 \mathrm{bc}$ & chromatin \\
\hline & & & & & & & STH $5.8421 \mathrm{e}$ & & & & & $0^{d}$ & $\mathrm{n} / \mathrm{a}$ \\
\hline
\end{tabular}




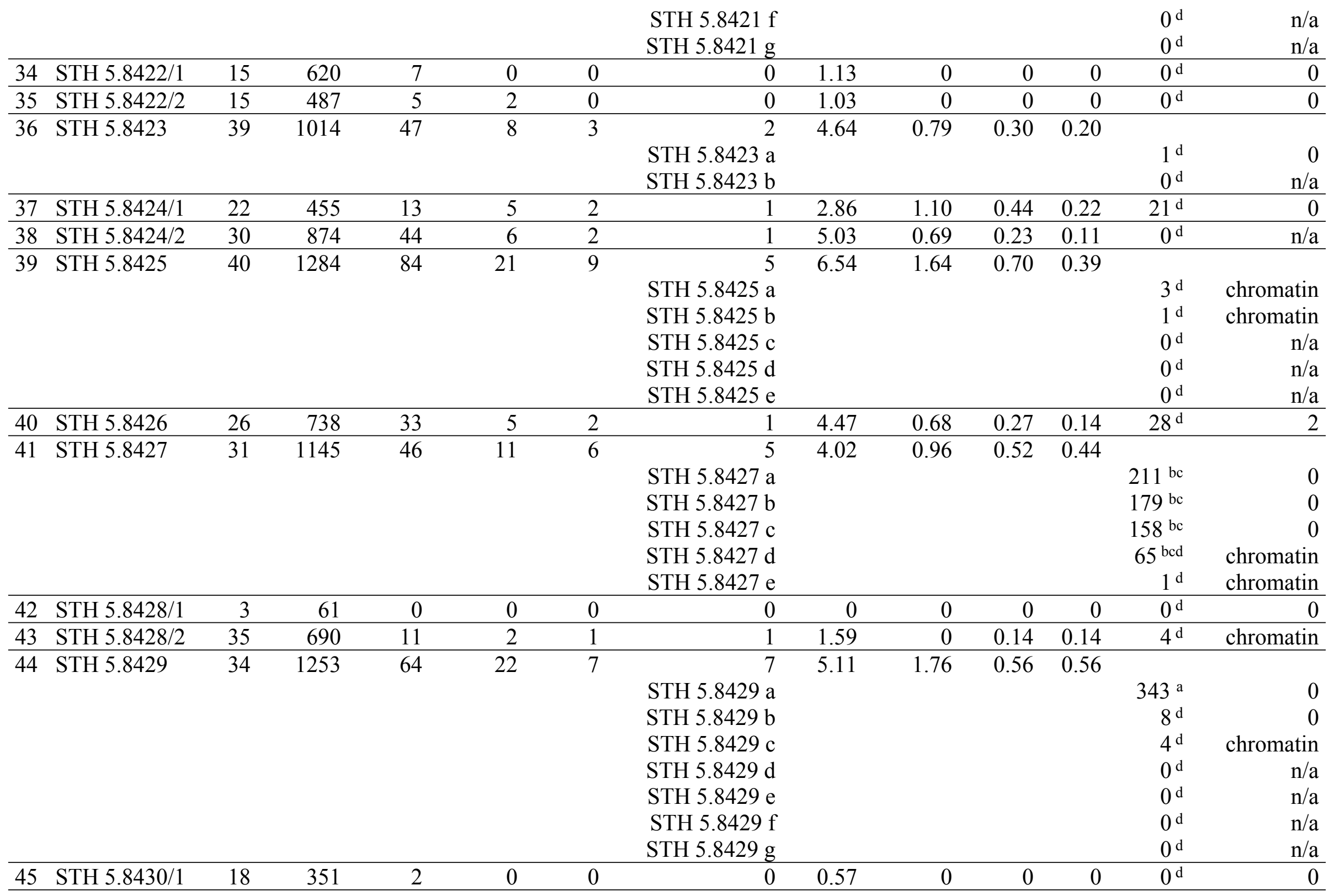




\begin{tabular}{|c|c|c|c|c|c|c|c|c|c|c|c|c|c|}
\hline 46 & STH 5.8430/2 & 17 & 307 & 17 & 3 & 1 & 1 & 5.54 & 0.98 & 0.33 & 0.33 & $130^{b c}$ & 0 \\
\hline 47 & STH 5.8432 & 32 & 698 & 29 & 4 & 1 & 1 & 4.15 & 0.57 & 0.14 & 0.14 & $58 \mathrm{~cd}$ & 0 \\
\hline \multirow[t]{3}{*}{48} & STH 5.8436 & 39 & 799 & 24 & 3 & 2 & 2 & 3.00 & 0.38 & 0.25 & 0.25 & & \\
\hline & & & & & & & STH $5.8436 \mathrm{a}$ & & & & & $58 \mathrm{~cd}$ & 0 \\
\hline & & & & & & & STH 5.8436 b & & & & & $8^{d}$ & 2 \\
\hline \multirow[t]{3}{*}{49} & STH 5.8440 & 35 & 817 & 43 & 7 & 2 & 2 & 5.26 & 0.86 & 0.24 & 0.24 & & \\
\hline & & & & & & & STH $5.8440 \mathrm{a}$ & & & & & $96^{b c d}$ & 0 \\
\hline & & & & & & & STH $5.8440 \mathrm{~b}$ & & & & & $51 \mathrm{~cd}$ & chromatin \\
\hline \multirow[t]{3}{*}{50} & STH 5.8449 & 38 & 844 & 21 & 4 & 2 & 2 & 2.49 & 0.47 & 0.24 & 0.24 & & \\
\hline & & & & & & & STH 5.8449 a & & & & & $70 \mathrm{bcd}$ & 0 \\
\hline & & & & & & & STH 5.8449 b & & & & & $55^{\mathrm{cd}}$ & chromatin \\
\hline 51 & STH 5.8450 & 30 & 628 & 27 & 0 & 0 & 0 & 4.30 & 0 & 0 & 0 & $0^{d}$ & 0 \\
\hline & STH 5.8458 & 34 & 727 & 27 & 4 & 2 & 2 & 3.71 & 0.55 & 0.28 & 0.28 & & \\
\hline & & & & & & & STH 5.8458 a & & & & & $57^{\mathrm{cd}}$ & 0 \\
\hline & & & & & & & STH $5.8458 \mathrm{~b}$ & & & & & $35^{d}$ & 2 \\
\hline 53 & STH 5.8460 & 25 & 511 & 16 & 1 & 0 & 0 & 3.13 & 0 & 0 & 0 & $0^{\mathrm{d}}$ & 0 \\
\hline & STH 5.8504 & 22 & 840 & 25 & 9 & 4 & 2 & 2.98 & 1.07 & 0.48 & 0.24 & & \\
\hline & & & & & & & STH $5.8504 \mathrm{a}$ & & & & & $2^{d}$ & 0 \\
\hline & & & & & & & STH $5.8504 \mathrm{~b}$ & & & & & $5^{d}$ & 1 \\
\hline \multirow[t]{4}{*}{55} & STH 5.8504/1 & 25 & 808 & 34 & 15 & 7 & 3 & 4.21 & 1.86 & 0.87 & 0.37 & & \\
\hline & & & & & & & STH $5.8504 / 1 \mathrm{a}$ & & & & & $2^{d}$ & 0 \\
\hline & & & & & & & STH $5.8504 / 1 \mathrm{~b}$ & & & & & $0^{d}$ & $\mathrm{n} / \mathrm{a}$ \\
\hline & & & & & & & STH $5.8504 / 1 \mathrm{c}$ & & & & & $0^{\mathrm{d}}$ & $\mathrm{n} / \mathrm{a}$ \\
\hline \multirow[t]{4}{*}{56} & STH 5.8505 & 27 & 946 & 33 & 10 & 4 & 3 & 3.49 & 1.06 & 0.42 & 0.32 & & \\
\hline & & & & & & & STH $5.8505 \mathrm{a}$ & & & & & $19^{d}$ & 0 \\
\hline & & & & & & & STH 5.8505 b & & & & & $0^{d}$ & $\mathrm{n} / \mathrm{a}$ \\
\hline & & & & & & & STH 5.8505 c & & & & & $0^{d}$ & $\mathrm{n} / \mathrm{a}$ \\
\hline 57 & STH 5.8505/1 & 27 & 707 & 16 & 5 & 2 & 1 & 2.26 & 0.71 & 0.28 & 0.14 & $3^{d}$ & 0 \\
\hline & STH 5.8506 & 22 & 644 & 30 & 13 & 4 & 3 & 4.66 & 2.02 & 0.62 & 0.47 & & \\
\hline & & & & & & & STH 5.8506 a & & & & & 84 bcd & 0 \\
\hline & & & & & & & STH 5.8506 b & & & & & $12^{d}$ & 1 \\
\hline & & & & & & & STH $5.8506 \mathrm{c}$ & & & & & $0^{d}$ & $\mathrm{n} / \mathrm{a}$ \\
\hline & STH 5.8506/1 & 24 & 644 & 19 & 6 & 2 & 1 & 2.95 & 0.93 & 0.31 & 0.16 & 99 bcd & 0 \\
\hline
\end{tabular}




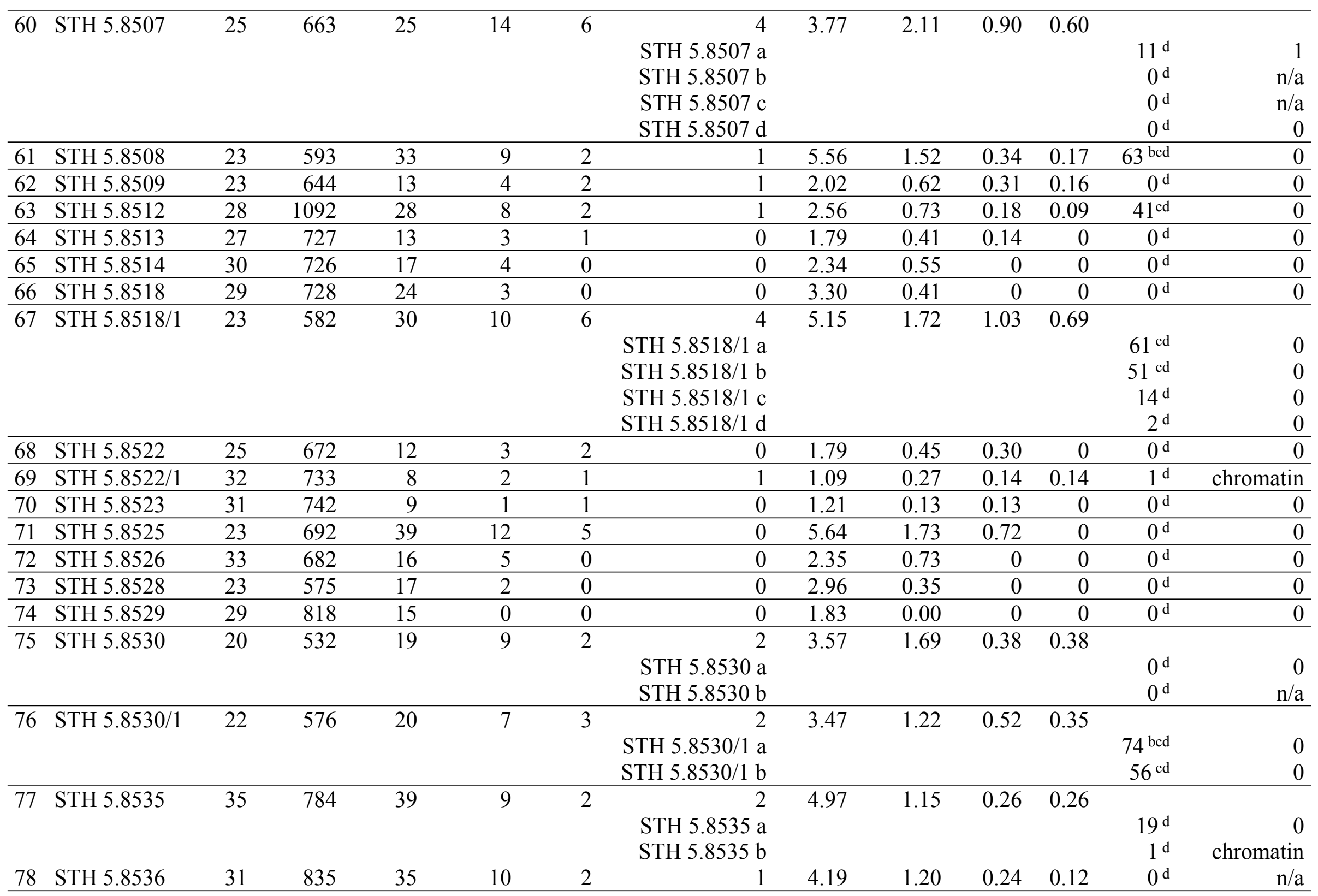




\begin{tabular}{|c|c|c|c|c|c|c|c|c|c|c|c|c|c|}
\hline \multirow[t]{3}{*}{79} & STH 5.8536/1 & 25 & 774 & 32 & 7 & 2 & 2 & 4.13 & 0.90 & 0.26 & 0.26 & \multirow{2}{*}{\multicolumn{2}{|c|}{$1^{\mathrm{d}} \quad$ chromatin }} \\
\hline & & & & & & & STH 5.8536/1 a & & & & & & \\
\hline & & & & & & & STH $5.8536 / 1 \mathrm{~b}$ & & & & & $0^{d}$ & 0 \\
\hline \multirow[t]{5}{*}{80} & STH 5.8540 & 29 & 908 & 22 & 5 & 1 & 1 & 2.42 & 0.55 & 0.11 & 0.11 & $0^{\mathrm{d}}$ & 0 \\
\hline & Total & 2314 & 57515 & 2129 & 601 & 210 & 138 & & & & & 4371 & \\
\hline & Average & & & & & & & 3.58 & 0.99 & 0.34 & 0.21 & & \\
\hline & Min. & & & & & & & 0 & 0 & 0 & 0 & & \\
\hline & Max. & & & & & & & 9.69 & 2.63 & 1.83 & 1.46 & & \\
\hline
\end{tabular}

3 


\section{Table 2 (on next page)}

Analysis of variance of haploid embryos formation and lines production depending on oat genotype as well as seeds production depending on oat hybrids

SS sum of squares, df degrees of freedom, MS mean squares, * significant at $p \leq 0.05$, ns not significant $p \leq 0.05$ 
1

2

\begin{tabular}{lrrrrrr}
\hline Trait & SS & df & MS & MS for residual & F & p \\
\hline Embryos formation & 217.13 & 79 & 2.895 & 34.464 & 0.084 & $0.751 \mathrm{~ns}$ \\
Lines production & 6.27 & 79 & 0.084 & 0.024 & 3.457 & $0.116 \mathrm{~ns}$ \\
$\begin{array}{l}\text { DH/OMA seeds } \\
\text { production }\end{array}$ & 49347.9 & 1 & 49347.9 & 2607.8 & 18.923 & $0.000 *$ \\
\hline
\end{tabular}

3

4 


\section{Figure 1}

Oat haploid embryo formed after crossing with maize

(A); germinated haploid embryo on 190-2 medium (B); haploid plant on MS medium (C); acclimatization of haploid plant in perlite (D); DH plants in the greenhouse (E); panicles of OMA line STH5.8536/1, some of immature panicles are senesced (F); grassy OMA line STH5.8429 without panicles (G). Photo credit: Edyta Skrzypek.
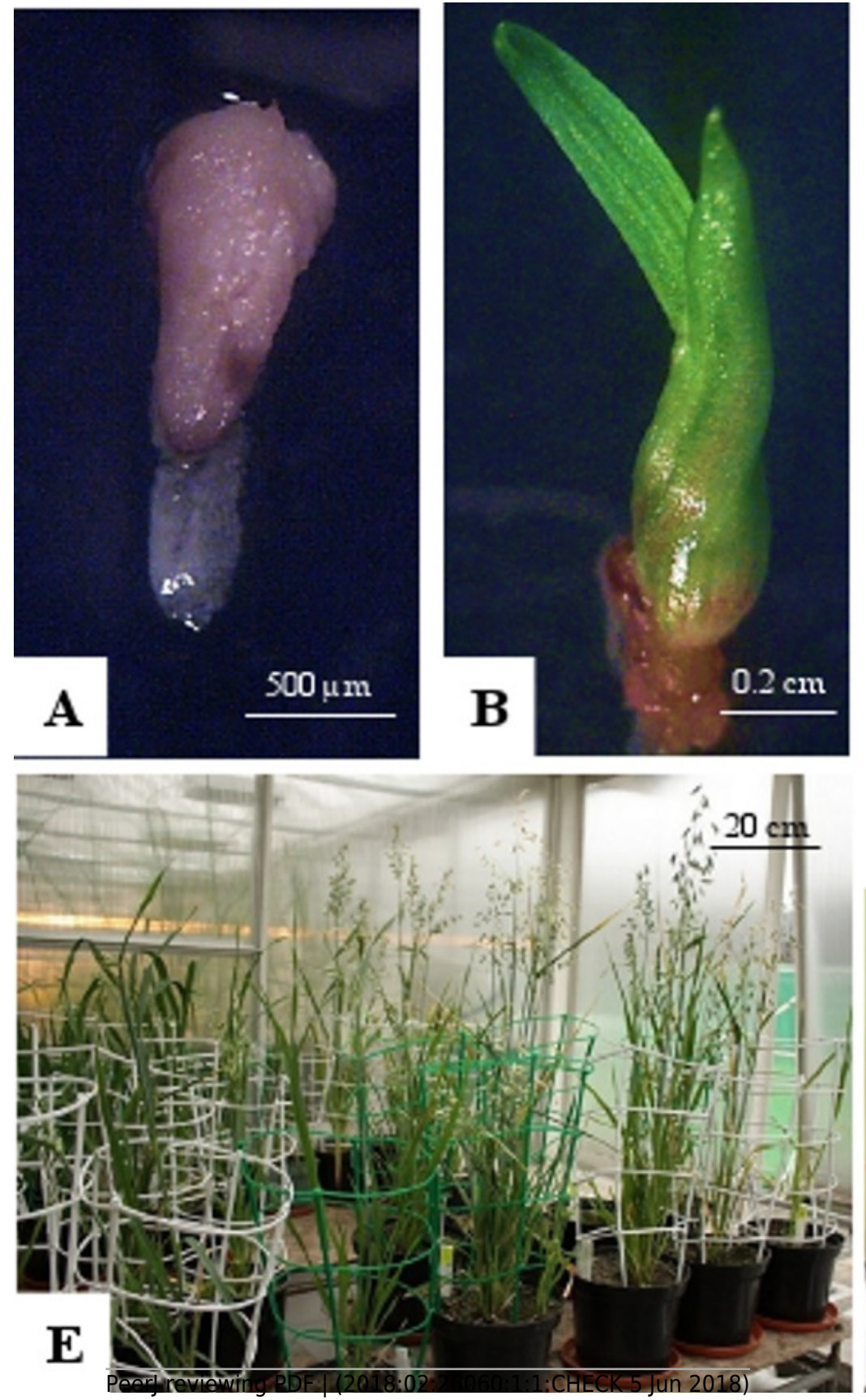
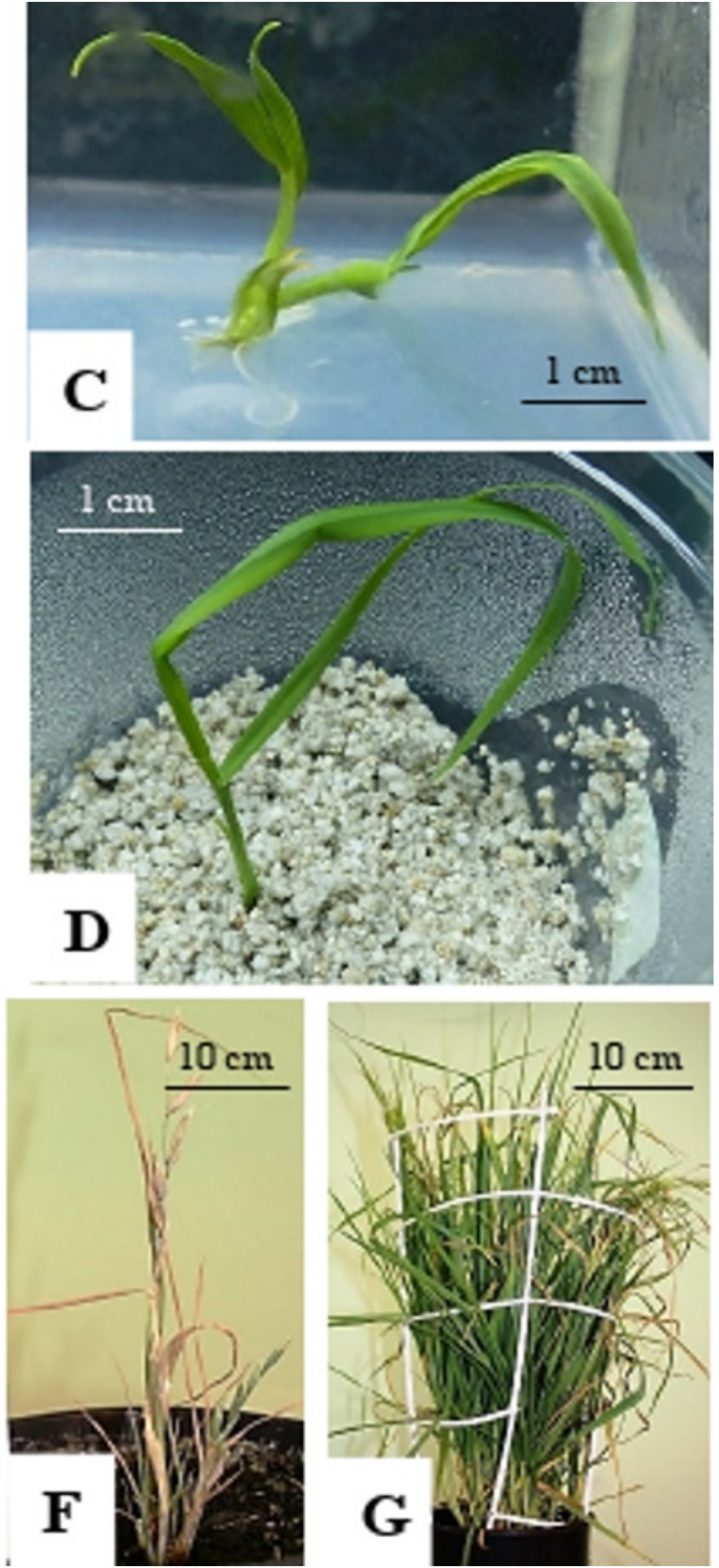
Figure 2

Flow cytometry histograms of oat plants; (A) control 2n, (B) doubled haploid $2 n,(C)$ haploid $1 \mathrm{n}$ and (D) mixoploid
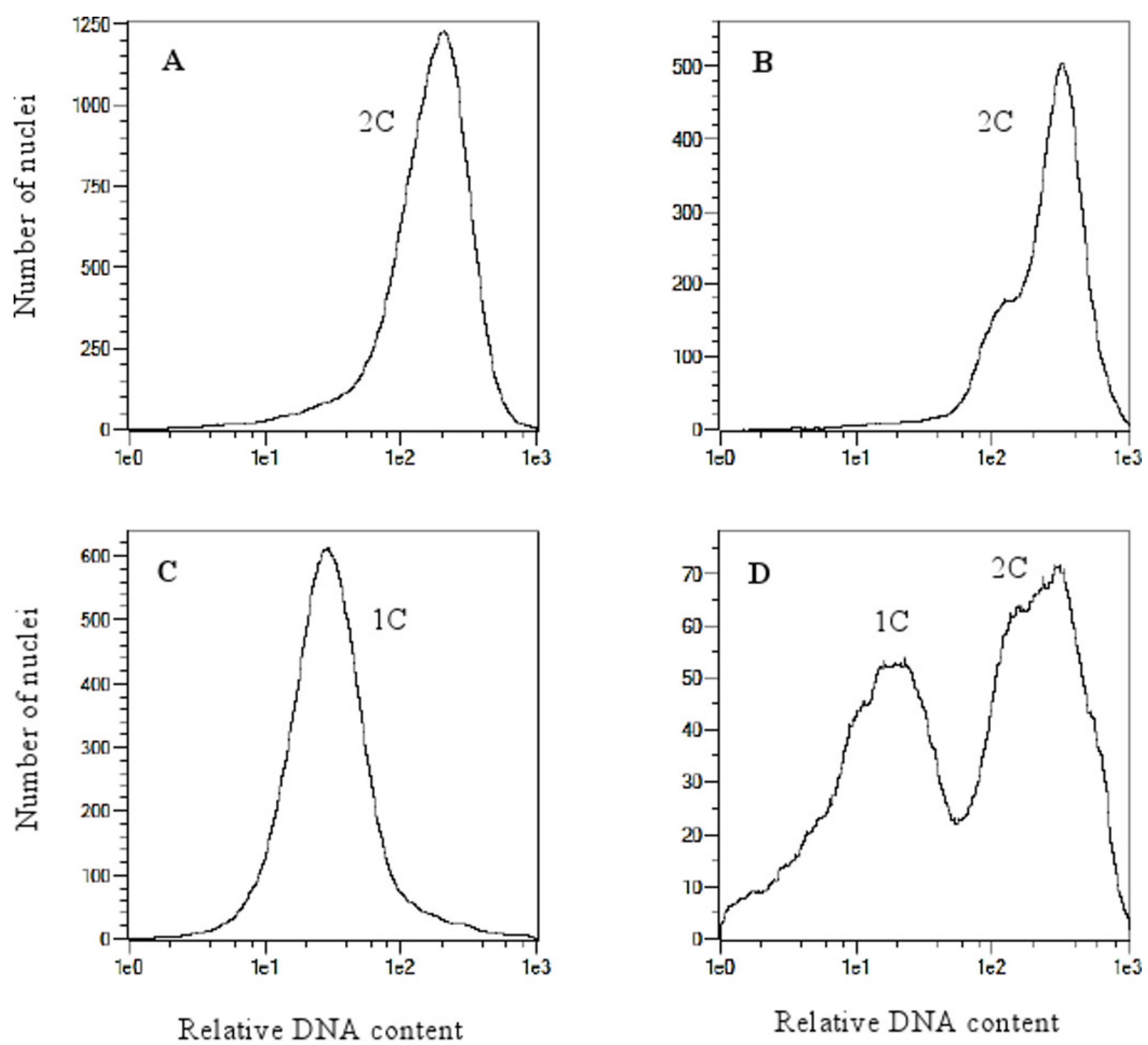


\section{Figure 3}

Identification of oat $\times$ maize F1 plants

PCR products of genomic DNA of oat, maize, and a selection of 22 oat $\times$ maize F1 plants shown after electrophoresis in 1.5\% (w/v) agarose gel. Bands represent 500 bp DNA fragments that were amplified with marker Grande-1. Marker leader is shown in the first line. Maize cv. Waza specificity is shown by product presence in maize DNA (positive control) and absence in oat cV. Stoper DNA (negative control). The presence of retained maize chromosomes is indicated in 14 out of the $22 F_{1}$ plant DNAs shown. Photo credit: Tomasz Warzecha.

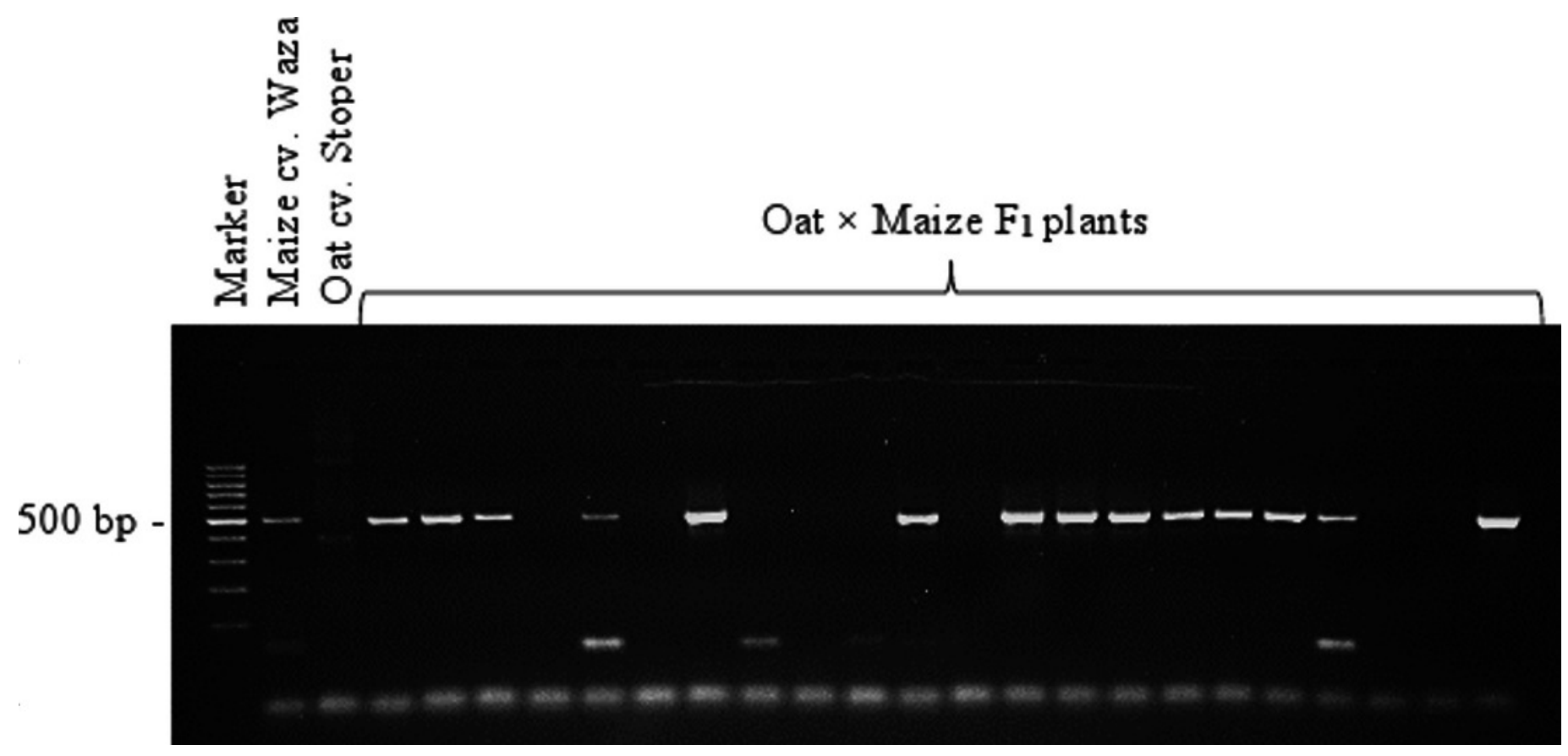




\section{Figure 4}

Visualization of added maize chromosomes in oat genome by genomic in situ hybridization (GISH).

A - STH 4.4690 f plant with tetrasomic addition of maize; B - STH 5.8504bplant with monosomic addition of maize chromosome, C - STH 5.8436b plant with disomic addition of maize chromosome. The maize chromosomes are labelled uniformly, D - STH 4.4576 plant with disomic addition of maize chromosome. A banding pattern is visible on additional chromosomes. Maize gDNA is labeled with digoxigenin and detected anti-dig FITC (green fluorescence), rhodamine-5-dUTP - labeled 25S rDNA (red fluorescence) is used as an internal control of hybridization efficiency. Chromosomes are stained with DAPI (blue fluorescence). Scale bar: $10 \mu \mathrm{m}$. Photo credit: Dominika Idziak-Helmcke. 

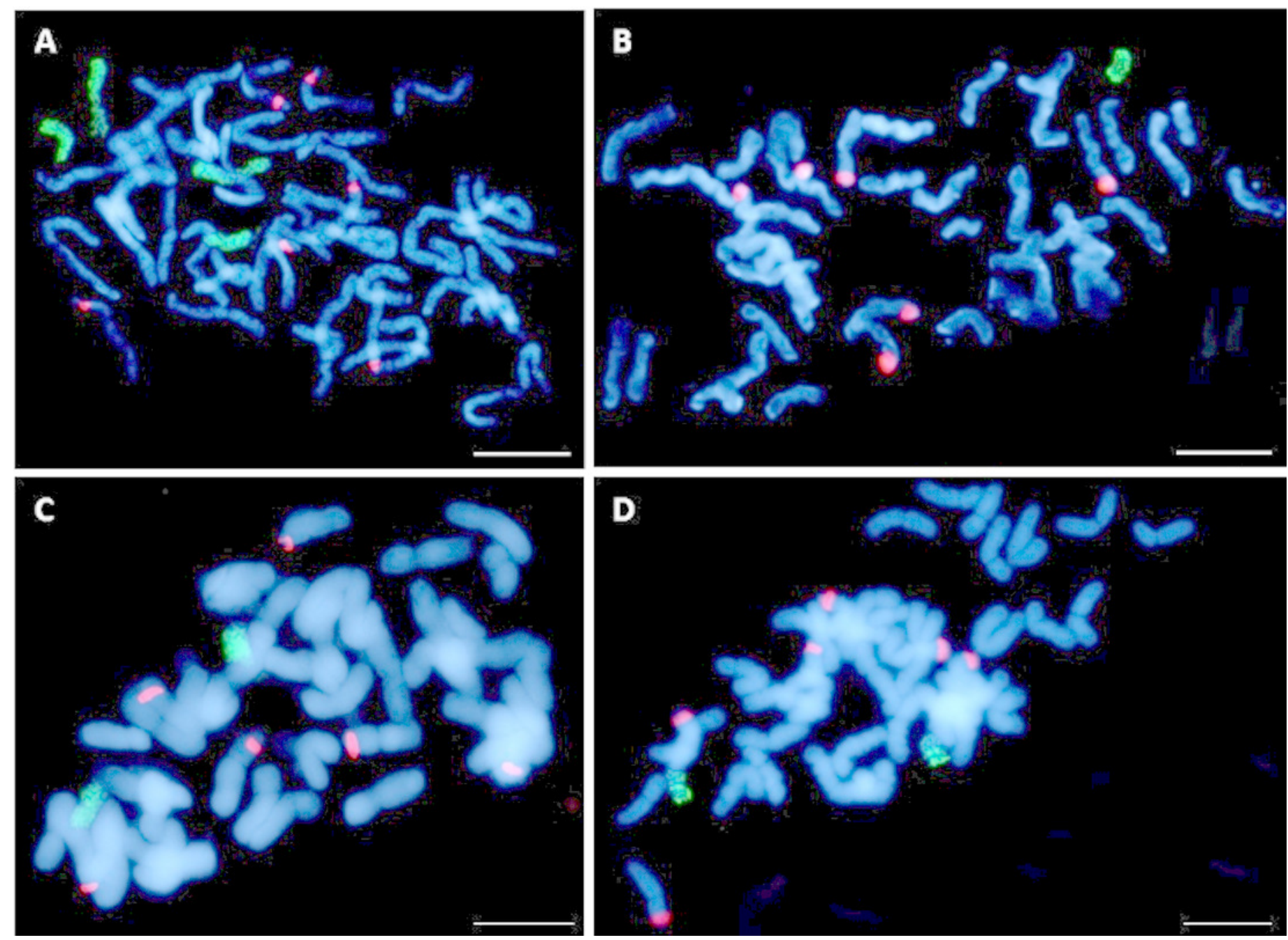


\section{Figure 5}

Visualization of added fragments of maize chromosomes in oat genome by genomic in situ hybridization (GISH)

A - STH 4.4690d; B - STH 4.4576; C - STH 4.4606 F1 plants. The arrows point to maize introgressions into oat chromosomes (green fluorescence). Yellow signals result from colocalization of hybridization signals for maize gDNA (green fluorescence) and 25S rDNA (red fluorescence). Chromosomes are stained with DAPI (blue fluorescence). Scale bar: 10 $\mu \mathrm{m}$. Photo credit: Dominika Idziak-Helmcke.

*Note: Auto Gamma Correction was used for the image. This only affects the reviewing manuscript. See original source image if needed for review.
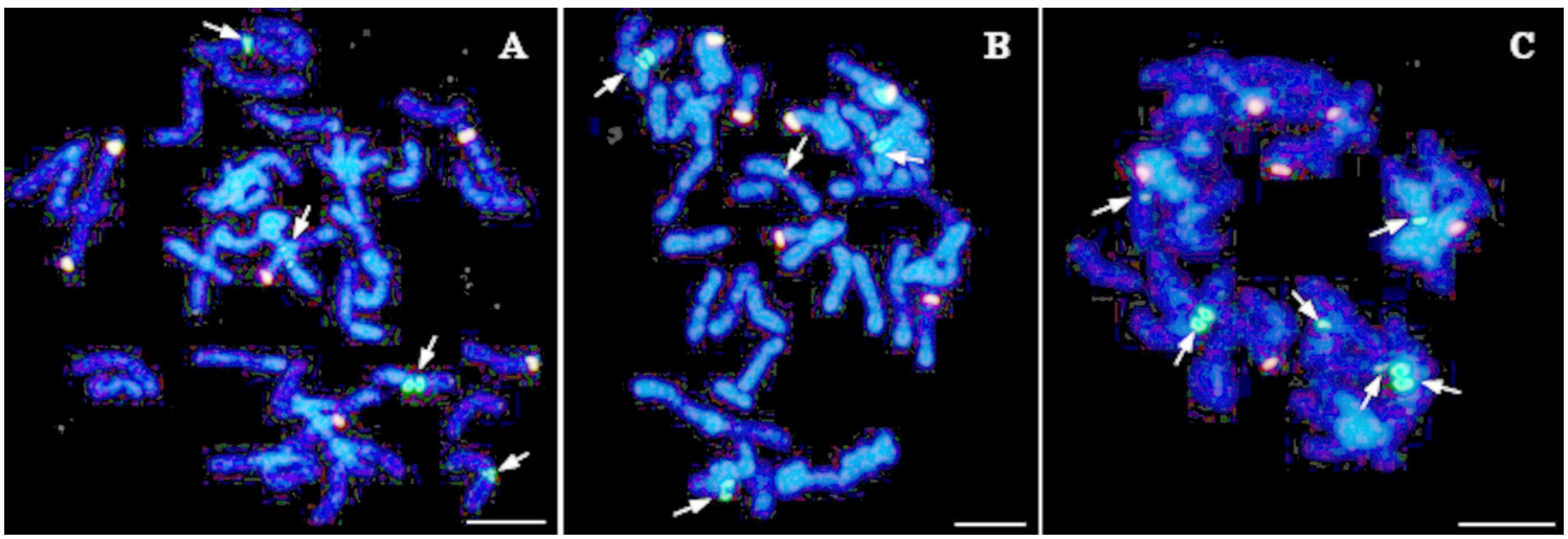